\title{
22. EVIDENCE FOR SURFACE-WATER CIRCULATION CHANGES AT SITE 851 IN THE EASTERN TROPICAL PACIFIC OCEAN ${ }^{1}$
}

\author{
A.C. Ravelo ${ }^{2}$ and N.J. Shackleton ${ }^{3}$
}

\begin{abstract}
This study investigates changes in the upper water column hydrography at Site 851 of the eastern tropical Pacific Ocean since the late Pliocene, using the oxygen and carbon isotopic composition of three species of planktonic foraminifers, each calcifying at different depths in the photic zone. The upper ocean seasonal hydrography in this region responds to the seasonally changing trade winds and thus is expected to respond to past changes in trade winds. One major change occurs at about $1.5 \mathrm{Ma}$, when the thermocline adjusts from a deep position to a shallower position. The thermocline remains in a relatively shallow position throughout the record up to recent time, with slight variations occurring synchronously with glacial/interglacial stages. In glacials, SSTs are probably a few degrees cooler and the thermocline is slightly deeper. From our knowledge of seasonal and interannual adjustments of the thermocline in this location, a deeper thermocline might be interpreted as either a decrease in the strength of the Equatorial Undercurrent (EUC) that results from lower mean wind strength or an increase in the Equatorial Countercurrent (ECC), which results from an increase in the strength of the southeasterly trade winds. A major shift from higher to lower carbon isotope values occurred at about $1.9 \mathrm{Ma}$, marking a transition to reduced planktonic-benthic $\delta^{13} \mathrm{C}$ differences after $1.9 \mathrm{Ma}$. The carbon isotopic data indicate that changes in the carbon isotopic composition of intermediate upwelling water occurs at higher frequencies than the glacial/interglacial changes in ice volume.
\end{abstract}

\section{INTRODUCTION}

Surface-water circulation in the tropical Pacific Ocean primarily is driven by the trade wind system, which is centered about the Intertropical Convergence Zone (ITCZ) located north of the equator. Extratropical conditions, such as the distribution and orography of ice sheets, the land-sea distribution, and the equator to pole temperature gradient, may affect the tropical atmospheric circulation pattern. A small, but significant effect on the trade winds from changing extratropical boundary conditions has been generated by general circulation models (GCMs) (Williams et al., 1974; Gates, 1976; Manabe and Hahn, 1977; Manabe and Broccoli, 1983; Kutzbach and Guetter, 1986; and Rind, 1987). In addition, changes in the seasonality of solar insolation from the precession of the equinox may also influence the seasonality, and possibly mean strength, of the trade winds. The influence of the seasonal insolation on tropical circulation has also been modeled with GCMs (Kutzbach, 1981; Kutzbach and Otto-Bleisner, 1982; Kutzbach and Street-Perrott, 1985; and Kutzbach and Guetter, 1986); however, the largest influence of changes on seasonal insolation is in the Atlantic and Indian Ocean tropics, rather than in the Pacific.

Eolian and geochemical studies in the tropical Pacific suggest that stronger trade winds occurred during past glacial periods (e.g., Boyle, 1983; Janecek and Rea, 1985; Chuey et al., 1987), while the study of Pisias and Rea (1988) suggested that maxima in the strength of trade winds and equatorial divergence do not simply occur during glacials. Many studies have used sedimentological, chemical, and faunal indicators of increased productivity, which may be tied to increased wind-forced upwelling (Berger, 1973; Johnson and Knoll, 1974; Andelseck and Anderson, 1978; Moore et al., 1980; Berger et al., 1983; Pedersen, 1983; Pisias and Rea, 1988; and Sarnthein et al., 1988). Some studies argued that sedimentological indicators of productivity may have been the result of changes in preservation, or to changes in factors other than upwelled nutrient availability (Farrell and Prell, 1989; Lyle, 1988; and Lyle, 1992). In fact, photic zone productivity

${ }^{1}$ Pisias, N.G., Mayer, L.W., Janecek, T.R., Palmer-Julson, A., and van Andel, T.H. (Eds.), 1995. Proc. ODP, Sci. Results, 138: College Station, TX (Ocean Drilling Program).

${ }^{2}$ Marine Sciences Board, University of California, Santa Cruz, CA 95064, U.S.A.

${ }^{3}$ University of Cambridge, Godwin Laboratory, Free School Lane, Cambridge CB2 3RS, United Kingdom. and nutrient measurements from the equatorial Pacific indicate that south of the equatorial divergence area there is a decrease in productivity and an increase in nutrient levels (Chavez, et al., 1990). Some recent research (Lyle et al., 1991; Mix et al., 1991; and Pisias et al., 1991) suggested that a link exists between increased productivity and increased upwelling during glacials. However, the link between deepsea sediment indicators of surface paleoceanography and wind forcing still is not well understood.

The purpose of this study is to reconstruct past changes in the thermocline structure over the last $2.0 \mathrm{Ma}$ to predict past changes in the wind field. This study is designed to look at how the thermocline is recorded by the oxygen and carbon stable isotopes in depth-stratified planktonic foraminifers. Reconstructing the past physical conditions of the thermocline is a way of looking at wind-driven oceanic changes independent from changes in productivity. It is a way of avoiding the ambiguities for interpreting wind-field changes from sedimentological indicators of productivity.

\section{CIRCULATION AND HYDROGRAPHY}

Tropical Pacific Ocean surface and subsurface water circulation has been described in many observational (e.g., Wyrtki, 1966; Meyers, 1979; and Halpern and Weisberg, 1991) and modeling (e.g., Philander and Pacanowski, 1980; Philander and Chao, 1991) studies. Tropical circulation is primarily driven by the seasonally varying trade winds, which generally drive surface water from east to west, allowing for cool intermediate waters to upwell in the east and warmer waters to "pile up" in the west. This circulation also drives divergent upwelling along the equator. In the southeastern tropics, at the location of Site 851 , winds are strongest during the Northern Hemisphere summer when the ITCZ is in its northernmost position, and weakest during the winter when the ITCZ is in its southernmost position (just north of the equator). East of about $90^{\circ} \mathrm{W}$, the trades have a strong south-north component that drives Peruvian coastal upwelling south of the equator. Nearing the equator, the trade winds, which have a stronger east-west component, drive the advection of the cool coastal upwelling waters (the Peru Current) from off the coast of Peru into the equatorial current system within the South Equatorial Current (SEC). The origin of the high nutrient cold tongue along the eastern equatorial region is from intermediate water that upwelled off 
the Peruvian margin (Toggweiler et al., 1991). The seasonal thermocline is within the photic zone most of the year in the eastern tropics owing to the intensity of upwelling and advection of cool nutrientrich intermediate waters into the photic zone.

Site 851 is on the northern edge of the SEC and is slightly influenced by the return flow of warm water from the west to the east within the Equatorial Countercurrent (ECC), which depresses the thermocline along its path. In the subsurface, seasonal variation in the depth of the thermocline is influenced both by divergent upwelling, but mostly by the strength of the Equatorial Undercurrent (EUC), which advects western tropical water to the east at a depth that shoals to about $100 \mathrm{~m}$ at the longitude of Site 851. The EUC, driven by the pressure gradient set up by the east to west advection of surface water, is one of the most important currents influencing the thermocline depth across the entire equatorial zone and is strongest in April, after the maximum in the northeast trade winds. Thus, around April, the thermocline is at its shallowest position at the location of Site 851 . The trade winds, by setting up the pressure gradient that drives the EUC, and by driving upwelling and the equatorial currents, are responsible for the complicated three-dimensional structure of the thermocline.

The temperature profiles in Figure 1 give an idea of the seasonal movements of the thermocline at the location of Site 851. The modern temperature profiles at the 2.5-Ma backtracked location of Site 851 (Duncan and Clague, 1985) also is shown to demonstrate that hydrography is not significantly different and, therefore, hydrographic changes recorded in the sediments cannot simply be related to the paleolocation of the site. In sum, as illustrated in Figure 1, the thermocline is deepest during the season of the maximum in the southeast trade winds when the SEC and the ECC are the strongest and when the ITCZ is located in its northernmost position. The thermocline shoals when the ITCZ moves to its southernmost position in February through April (winds at this location are at a minimum) and remains shallow through the period of the maximum in the strength of the EUC until almost June. As the ITCZ moves back north again and the winds at Site 851 increase, the thermocline deepens.

\section{METHODS}

Samples, taken at 10-cm intervals, were chosen from Holes 851B, $851 \mathrm{C}$, and $851 \mathrm{E}$ to produce a continuous record over the last $2.4 \mathrm{Ma}$ for $G$. sacculifer and $1.85 \mathrm{Ma}$ for $G$. tumida and $N$. dutertrei. This sampling interval represents a temporal resolution of about 4-5 k.y. Gaps in the record are due to a particular species being absent from a sample. Sampling strategy was designed by correlating among holes using GRAPE measurements, such that Hole $851 \mathrm{E}$ was used as the backbone of the record, and Holes $851 \mathrm{~B}$ and $851 \mathrm{C}$ were used to patch between the Hole $851 \mathrm{E}$ core breaks. Foraminifers were selected from the 335 to $425-\mu \mathrm{m}$ fraction, and selected specimens of $G$. sacculifer were analyzed in the isotope laboratory at the University of Cambridge, following the methods described in Shackleton et al. (this volume). Analytical reproducibility is typically about $\pm 0.06 \%$ o $(1 \sigma)$ for $\delta^{18} \mathrm{O}$ and somewhat better for $\delta^{13} \mathrm{C}$. Selected specimens from the 335 - to $425-\mathrm{mm}$ fraction of $G$. tumida and $N$. dutertre $i$ were analyzed in the isotope laboratory at the University of Bergen, where samples first were ultrasonically cleaned in methanol and then roasted in vacuum for $40 \mathrm{~min}$ at $380^{\circ} \mathrm{C}$. Isotope measurements at the University of Bergen were performed using a Finnigan MAT 251 mass spectrometer fitted on line to a reaction line, following the description of Shackleton et al. (1983). Analytical reproducibility is typically about $\pm 0.07 \%$ for $\delta^{18} \mathrm{O}$ and $\pm 0.06 \%$ for $\delta^{13} \mathrm{C}$, reported at $1 \sigma$. All values (Table 1) have been reported relative to PDB, based on calibrations in each laboratory to NBS-19.

The age model used is a combination of that developed by GRAPE tuning (Shackleton et al., this volume) and more detailed correlation of the $G$. sacculifer oxygen isotopic curve to the oxygen isotopic stratigraphy reported in Shackleton et al. (1990). In sections where the $G$. sacculifer record has gaps caused by decreases in abundances of this species, G. tumida was used. Essentially, the age model of Shackleton (this volume) was altered by optimizing the visual correlation of the oxygen isotopic curve to Site 677 (Shackleton et al., 1990). Oxygen isotope data from Site 851 was not tuned; rather it was correlated to the Site 677 record, which was tuned primarily using the precessional frequencies. The oxygen isotopic record of $G$. sacculifer with the age model of Shackleton (this volume) was compared to the age model developed here based primarily on oxygen isotopic stratigraphy. The age model primarily based on GRAPE tuning to insolation (Shackleton, this volume) is nearly identical to the age model based on the oxygen isotopic stratigraphy. This is not surprising since the GRAPE tuned age model was itself augmented with oxygen isotopic correlation. In any case, the fine-scale changes made here were intended to optimize the accuracy of the dating of fine-scale features of the isotopic curves of this study without changing the first-order dating provided by the GRAPE-tuning.

\section{VERTICAL STRATIFICATION OF PLANKTONIC FORAMINIFERS}

Vertical depth habitats of tropical planktonic foraminifers have been the subject of many plankton tow and sediment trap studies (Fairbanks et al., 1982; Curry et al., 1983; Ganssen and Sarnthein, 1983; Thunell et al., 1983; Thunell and Reynolds, 1984; Bé et al., 1985). A long history of reproducing vertical stratification using foraminifer from sediments exists (e.g., Emiliani, 1954, 1971; Lidz et al., 1968; Shackleton, 1968; Shackleton and Vincent, 1978; Durazzi, 1981; Vincent and Berger, 1981; Ganssen and Sarnthein, 1983; Ravelo and Fairbanks, 1992). While it is fairly straightforward to reconstruct the vertical position of species relative to each other from sediment samples using $\delta^{18} \mathrm{O}$, it is a far larger problem to determine the actual depth of the thermocline. This is simply because $\delta^{18} \mathrm{O}$ basically provides information regarding temperature of calcification, not depth of calcification. Thus, to reconstruct thermocline depth, foraminifer habitats must be well understood, and species analyzed for isotopes must be chosen based on their usefulness as indicators of absolute depth. A few studies have demonstrated that abundances (Thunell et al., 1983; Ravelo et al., 1990) and isotopes (Ravelo and Fairbanks, 1992) can be used to predict thermocline depth in the tropics. Our selection of three species to analyze for this study was based on the results of these previous studies.

The three species analyzed were Globigerinoides sacculifer, Neogloboquadrina dutertrei, and Globorotalia tumida. The closest plankton tow (Fairbanks et al., 1982) and sediment trap (Curry et al., 1983) studies are from the Panama Basin. These studies demonstrate that $G$. sacculifer calcifies in the nutrient-depleted mixed layer, thus its isotopic signature represents surface water, and that $N$. dutertrei calcifies in the thermocline in association with the maximum in chlorophyll concentrations, thus its isotopic signature represents the temperature and chemical composition at the depth of the thermocline. The depth of the thermocline, which is approximately coincident with the depth of the chlorophyll maximum, varies seasonally and probably varied in the past as a response to changes in the wind field. Therefore, the absolute calcification depth of $N$. dutertrei cannot be inferred from isotopic measurements of its shell. The calcification habitat of $G$. tumida is near the bottom of the photic zone, regardless of the depth of the thermocline (Ravelo and Fairbanks, 1992). In fact, G. tumida calcifies in different temperatures, depending on the depth of the thermocline and mixed layer and thus is a good indicator of hydrographic conditions at the bottom of the photic zone.

To illustrate how the oxygen isotopic gradients between these species can be used to reconstruct thermocline and mixed layer depth, we have plotted core top data from two locations in the Atlantic Ocean (from Ravelo and Fairbanks, 1992) and from two locations in the tropical Pacific (Fig. 2). Core top locations and isotopic data are given in Table 2. In the eastern tropical Pacific and Atlantic Oceans, where the depths of the thermocline and mixed layer are small, the range between $G$. tumida and $G$. sacculifer is large relative to the western 

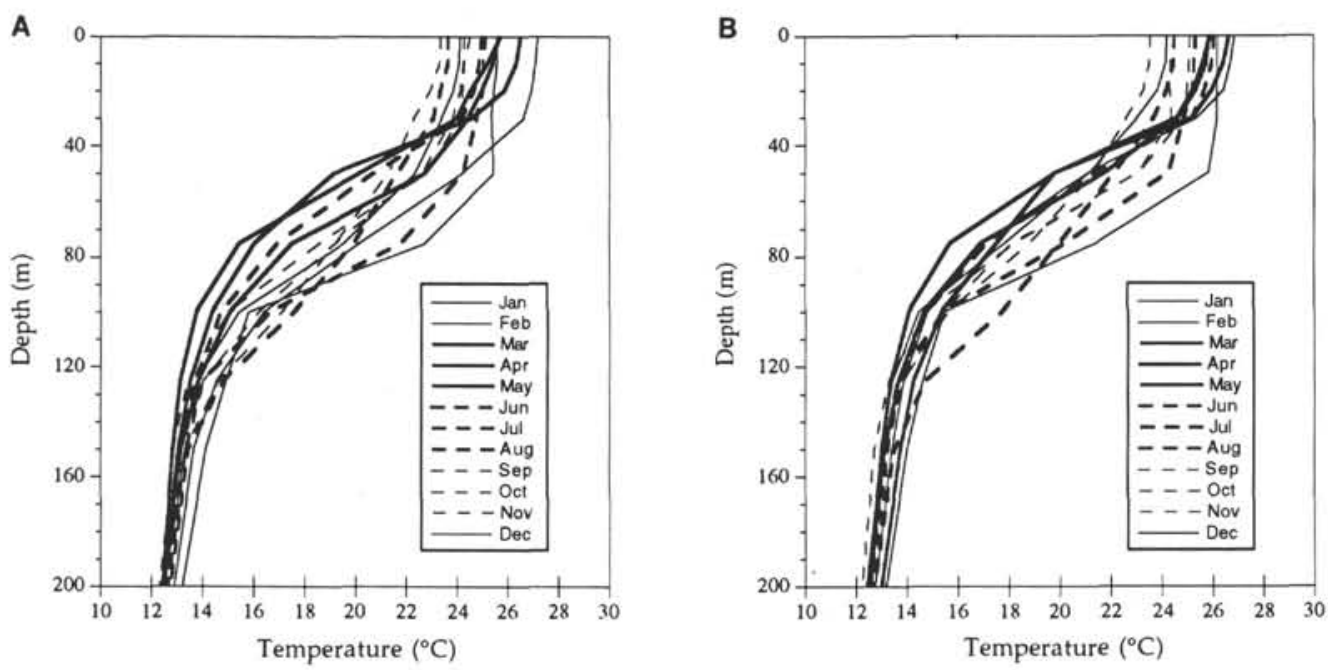

Figure 1.Temperature profiles (Levitus, 1982) from the location of Site 851 (A) and from the location of backtracked Site 851 (B) at $2.5 \mathrm{Ma}$.

Pacific and Atlantic, where the depths of the thermocline and mixed layer are greater. When the depth of the mixed layer is small, the thermocline is completely within the photic zone, and $G$. tumida is recording the cool temperatures below the thermocline at the base of the photic zone. When the depth of the mixed layer is large, the thermocline is either at the bottom or below the photic zone, and $G$. tumida is recording the slightly warmer temperatures of the upper thermocline. Thus, the difference in $\delta^{18} \mathrm{O}$ between $G$. tumid $a$ and $G$. sacculifer is related inversely to the depth of the mixed layer. $N$. dutertrei, on the other hand, calcifies in the thermocline, which is nearly the same temperature, regardless of the mixed layer depth. This can be seen in the data presented in Table 2 and Figure 2, and also in sediment trap data (Curry et al., 1983), which indicate that $\delta^{18} \mathrm{O}$ of $N$. dutertrei remains fairly constant throughout the year, despite fairly large changes in the depth of the thermocline. The difference in $\delta^{18} \mathrm{O}$ between $N$. dutertrei and $G$. sacculifer does not change much from locations with thin mixed layers, to locations with thick mixed layers, but the difference in $\delta^{18} \mathrm{O}$ between $G$. tumida and $N$. dutertrei is related inversely to the depth of the mixed layer. The measurements from core tops presented here are few, but they support our understanding of the depth of foraminifer depth habitats and form the basis of our interpretations of isotopic records of these three species.

\section{GENERAL TRENDS}

\section{Oxygen Isotopes}

All three species have slightly increasing $\delta^{18} \mathrm{O}$ values going from past to present (Fig. 3). This trend toward heavier values can be seen in benthic isotopic records from all over the world (e.g., Shackleton and Hall, 1984; Jansen et al., 1988; Shackleton and Hall, 1989; Raymo et al., 1990) and probably represents a global increase in the $\delta^{18} \mathrm{O}$ of seawater owing to an increase in the size of ice sheets during glacial periods. For all three species, glacial stages 6,8 , and 10 are relatively light compared to benthic records (e.g., Raymo et al., 1990). Normalizing (by subtracting the average) and comparing the $G$. sacculifer record with the benthic record from Site 677 (Fig. 4) illustrates that the amplitude of the $\delta^{18} \mathrm{O}$ variation is similar between these two records, with the exception of stages 6,8 , and 10 . Because Site 851 is located in a region having relatively large seasonal variations in surface-water conditions because of its sensitivity to wind field strength, it is most likely that the Site $677-851$ difference at stages 6,8 , and 10 result from temperature differences, with the Site 851 record being a less reliable indicator of ice volume. Stages 6,8 , and 10 may have been relatively warm glacial stages at the location of 851 compared with the previous
Tropical Atlantic and Pacific Core-tops S. G. sacculifer (D) N. dutentrei (T) G. tumida
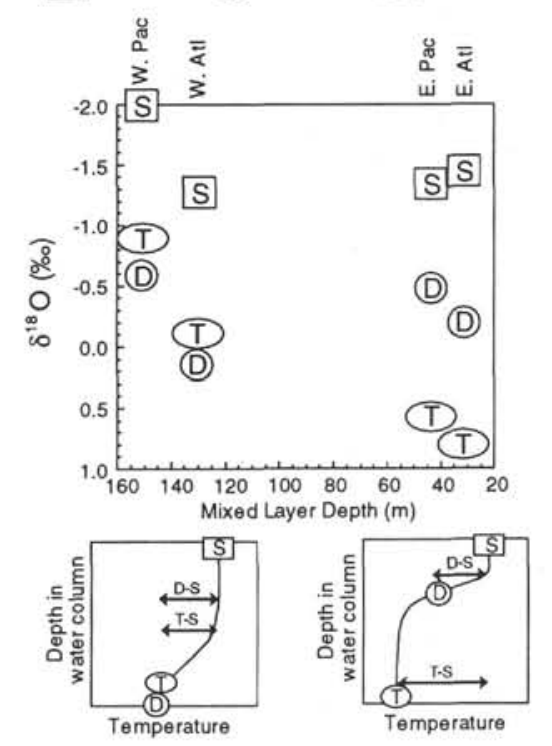

Figure 2. Ground-truth data for interpreting changes in the tropical thermocline. Regions having a deep thermocline will have smaller $G$. tumida-G. sacculifer and $G$. tumida-N. dutertrei differences.

and subsequent glacial periods. In Figures 5 and 6, the G. tumida and the $N$. dutertrei records have been compared to that of Site 677 showing that these two subsurface dwelling species are not high-quality recorders of glacial to interglacial changes in the global $\delta^{18} \mathrm{O}$ of seawater $\left(\delta_{w}\right)$. G. tumida is not expected to provide a good record of global $\delta_{w}$ because its vertical depth habitat is at the bottom of the photic zone, where large temperature variations occur in the eastern tropics. In addition, Figure 2 clearly shows that $G$. tumida grows at temperatures having a range of about $6^{\circ} \mathrm{C}$ between the eastern and western tropics; its oxygen isotopic value is a reflection of the subsurface hydrography. Although $G$. tumida is sensitive to local changes in hydrography, its record does resemble the Site 677 benthic record (which is probably primarily a $\delta_{w}$ signal) in some of the more recent isotopic stages (Fig. $5) . N$. dutertrei, on the other hand should theoretically be a good recorder of $\delta_{w}$ because it appears to calcify at nearly the same temperature regardless of hydrography. $N$. dutertrei calcifies within a rela- 
Table 1. Isotope data for Site 851 .

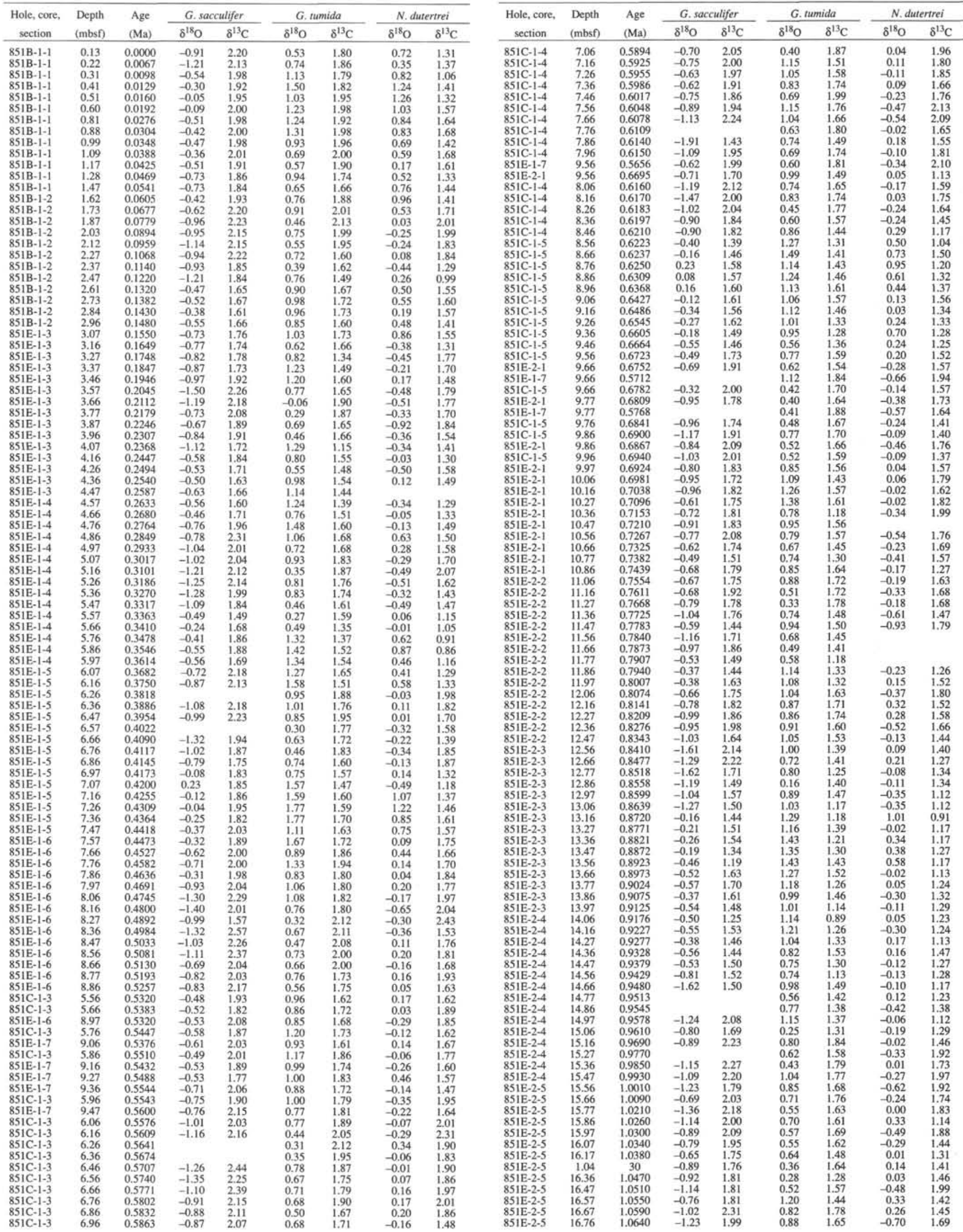


Table 1 (continued).

\begin{tabular}{|c|c|c|c|c|c|c|c|}
\hline Hole, core, & Depth & Age & G. sac & alifer & G.t & ida & $N \cdot d u$ \\
\hline & (mbsf) & & $8^{18} \mathrm{O}$ & $8^{13} \mathrm{C}$ & $8^{18} \mathrm{O}$ & $8^{13} \mathrm{C}$ & $8^{18} \mathrm{O}$ \\
\hline $851 \mathrm{E}-2-5$ & 16.86 & 1.0680 & -1.59 & 2.15 & 0.37 & 1.62 & -1.23 \\
\hline 851E-2-5 & 16.97 & 1.0740 & -1.29 & 2.05 & 0.49 & 1.41 & -0.21 \\
\hline $851 \mathrm{E}-2-6$ & 17.07 & 1.0790 & -1.04 & 1.90 & 0.64 & 1.42 & -0.15 \\
\hline $851 \mathrm{E}-2-6$ & 17.17 & 1.0850 & -0.87 & 1.85 & 0.58 & 1.50 & 0.30 \\
\hline 851 E-2-6 & 17.26 & 1.0910 & -1.04 & 1.86 & 0.83 & 1.51 & 0.03 \\
\hline $851 \mathrm{E}-2-6$ & 17.36 & 1.0960 & -0.85 & 1.77 & 1.06 & 1.63 & -0.46 \\
\hline $851 \mathrm{E}-2-6$ & 17.47 & 1.1020 & -0.84 & 2.09 & 0.60 & 1.55 & -0.07 \\
\hline $851 \mathrm{E}-2-6$ & 17.57 & 1.1080 & -1.22 & 1.96 & 0.19 & 1.64 & -0.86 \\
\hline $851 \mathrm{E}-2-6$ & 17.67 & 1.1130 & -1.23 & 1.87 & 0.31 & 1.55 & -0.17 \\
\hline $851 \mathrm{E}-2-6$ & 17.75 & 1.1170 & -0.88 & 1.72 & 0.29 & 1.42 & -0.41 \\
\hline 851 E-2-6 & 17.86 & 1.1220 & -0.87 & 1.71 & 0.87 & 1.15 & -0.13 \\
\hline $851 \mathrm{E}-2-6$ & 17.97 & 1.1260 & -0.67 & 1.63 & 0.96 & 1.40 & -0.44 \\
\hline $851 \mathrm{E}-2-6$ & 18.07 & 1.1310 & -0.74 & 1.61 & 0.99 & 1.52 & -0.14 \\
\hline 851E-2-6 & 18.17 & 1.1350 & -0.87 & 1.69 & 0.88 & 1.49 & -0.25 \\
\hline $851 \mathrm{E}-2-6$ & 18.26 & 1.1400 & -1.00 & 1.79 & 0.91 & 1.58 & -0.32 \\
\hline $851 \mathrm{C}-2-5$ & 18.01 & 1.1450 & -1.18 & 2.00 & 0.94 & 1.70 & -0.25 \\
\hline $851 \mathrm{E}-2-6$ & 18.36 & 1.1450 & -0.97 & 2.29 & 0.51 & 1.50 & -0.48 \\
\hline $851 C-2-5$ & 18.11 & 1.1510 & -1.20 & 2.41 & 0.94 & 1.75 & -0.49 \\
\hline $851 \mathrm{ic}-2-5$ & 18.21 & 1.1580 & -1.60 & 2.36 & 0.80 & 1.73 & -0.70 \\
\hline $851 C-2-5$ & 18.31 & 1.1640 & -1.20 & 2.12 & 0.69 & 1.47 & -0.54 \\
\hline $851 \mathrm{E}-2-7$ & 18.57 & 1.1540 & -1.11 & 2.34 & 0.85 & 1.55 & -0.63 \\
\hline $851 C-2-5$ & 18.41 & 1.1710 & -0.68 & 1.93 & 0.74 & 1.42 & -0.55 \\
\hline $851 \mathrm{E}-2-7$ & 18.67 & 1.1580 & -1.55 & 2.51 & 0.69 & 1.75 & -0.14 \\
\hline $851 C-2-5$ & 18.51 & 1.1780 & -1.02 & 2.08 & 0.88 & 1.32 & -0.35 \\
\hline $851 C-2-5$ & 18.61 & 1.1840 & -0.95 & 2.00 & 0.60 & 1.46 & -0.21 \\
\hline $851 \mathrm{E}-2-7$ & 18.76 & 1.1630 & -1.41 & 2.49 & 0.70 & 1.69 & -0.81 \\
\hline $851 C-2-5$ & 18.71 & 1.1900 & -0.66 & 1.88 & 1.09 & 1.13 & -0.52 \\
\hline $851 \mathrm{E}-2-7$ & 18.86 & 1.1680 & & & 1.01 & 1.44 & -0.50 \\
\hline $851 C-2-5$ & 18.81 & 1.1970 & $-0,48$ & 1.84 & 0.71 & 1.35 & 0.03 \\
\hline $851 \mathrm{E}-2-7$ & 18.97 & 1.1720 & & & 0.57 & 1.48 & 0.08 \\
\hline $851 C-2-5$ & 18.91 & 1.2040 & -0.61 & 1.69 & 1.27 & 1.39 & -0.06 \\
\hline $851 C-2-5$ & 19.01 & 1.2100 & -0.38 & 1.62 & 0.43 & 1.66 & -0.07 \\
\hline $851 \mathrm{E}-3-1$ & 19.06 & 1.2200 & -1.06 & 1.97 & 0.81 & 1.57 & -0.42 \\
\hline $851 \mathrm{E}-2-7$ & 19.07 & 1.1770 & & & 0.16 & 1.18 & -0.66 \\
\hline $851 C-2-5$ & 19.11 & 1.2170 & -0.70 & 1.72 & 1.12 & 1.45 & -0.16 \\
\hline $851 \mathrm{E}-3-1$ & 19.16 & 1.2260 & & & 0.72 & 1.47 & -0.54 \\
\hline $851 C-2-5$ & 19.21 & 1.2240 & -0.99 & 1.89 & 0.80 & 1.45 & 0.23 \\
\hline $851 \mathrm{E}-3-1$ & 19.26 & 1.2330 & -1.33 & 1.79 & 0.46 & 1.45 & -0.64 \\
\hline $851 \mathrm{C}-2-5$ & 19.31 & 1.2320 & -1.20 & 2.04 & 0.86 & 1.40 & -0.45 \\
\hline $851 \mathrm{E}-3-1$ & 19.36 & 1.2390 & -1.23 & 1.75 & 0.10 & 1.34 & -0.36 \\
\hline $851 C-2-5$ & 19.41 & 1.2390 & -1.30 & 2.00 & 0.95 & 1.61 & -0.57 \\
\hline $851 \mathrm{E}-3-1$ & 19.46 & 1.2430 & -1.06 & 1.67 & 0.60 & 1.02 & -0.47 \\
\hline 851E-3-1 & 19.56 & 1.2470 & -0.80 & 1.58 & 0.84 & 0.94 & -0.31 \\
\hline 851E-3-1 & 19.66 & 1.2510 & -0.38 & 1.45 & 1.46 & 1.35 & -0.13 \\
\hline 851E-3-1 & 19.76 & 1.2550 & -0.68 & 1.63 & 1.12 & 1.25 & -0.58 \\
\hline $851 \mathrm{E}-3-1$ & 19.86 & 1.2590 & & & 0.96 & 1.56 & -0.42 \\
\hline 851 E- $3-1$ & 19.96 & 1.2630 & -1.10 & 1.93 & 0.83 & 1.73 & -0.49 \\
\hline 851 E-3-1 & 20.06 & 1.2670 & -1.12 & 2.17 & 0.77 & 1.68 & -0.37 \\
\hline $851 \mathrm{E}-3-1$ & 20.16 & 1.2710 & -1.14 & 2.15 & 0.97 & 1.53 & -1.16 \\
\hline $851 \mathrm{E}-3-1$ & 20.26 & 1.2750 & -1.06 & 1.90 & 0.50 & 1.43 & -0.48 \\
\hline $851 \mathrm{E}-3-1$ & 20.36 & 1.2790 & -0.79 & 1.48 & 0.24 & 1.47 & -0.53 \\
\hline $851 \mathrm{E}-3-1$ & 20.46 & 1.2840 & -0.56 & 1.63 & 0.89 & 1.41 & -0.25 \\
\hline $851 \mathrm{E}-3-2$ & 20.56 & 1.2890 & -0.85 & 1.64 & 1.10 & 1.39 & -0.22 \\
\hline $851 \mathrm{E}-3-2$ & 20.66 & 1.2940 & -0.64 & 1.81 & 0.95 & 1.68 & -0.23 \\
\hline $851 \mathrm{E}-3-2$ & 20.76 & 1.2990 & -0.98 & 1.93 & 0.82 & 1.76 & -0.49 \\
\hline $851 \mathrm{E}-3-2$ & 20.86 & 1.3040 & -1.02 & 2.05 & 0.75 & 1.64 & -0.70 \\
\hline $851 \mathrm{E}-3-2$ & 20.96 & 1.3090 & -1.04 & 2.38 & 0.76 & 1.74 & -0.55 \\
\hline $851 \mathrm{E}-3-2$ & 21.06 & 1.3140 & -1.23 & 2.08 & 0.53 & 1.49 & -0.43 \\
\hline $851 \mathrm{E}-3-2$ & 21.16 & 1.3190 & -1.10 & 1.99 & 0.60 & 1.38 & -0.08 \\
\hline $851 \mathrm{E}-3-2$ & 21.26 & 1.3240 & -0.95 & 1.80 & 0.79 & 1.31 & -0.32 \\
\hline $851 \mathrm{E}-3-2$ & 21.36 & 1.3280 & -1.09 & 1.65 & 1.04 & 1.36 & -0.34 \\
\hline $851 \mathrm{E}-3-2$ & 21.46 & 1.3330 & -0.80 & 1.77 & 0.55 & 1.46 & -0.50 \\
\hline $851 \mathrm{E}-3-2$ & 21.56 & 1.3380 & -1.02 & 1.76 & 1.18 & 1.65 & -0.43 \\
\hline $851 \mathrm{E}-3-2$ & 21.66 & 1.3420 & & & 0.71 & 1.52 & -0.47 \\
\hline $851 \mathrm{E}-3-2$ & 21.76 & 1.3470 & & & 0.52 & 1.62 & -0.41 \\
\hline 851 E-3-2 & 21.86 & 1.3520 & & & 0.34 & 1.62 & -0.46 \\
\hline $851 \mathrm{E}-3-2$ & 21.96 & 1.3580 & & & 0.50 & 1.47 & -0.52 \\
\hline $851 \mathrm{E}-3-3$ & 22.06 & 1.3630 & & & 0.54 & 1.09 & -0.23 \\
\hline $851 \mathrm{E}-3-3$ & 22.16 & 1.3690 & -1.05 & 2.01 & 0.84 & 1.42 & -0.63 \\
\hline $851 \mathrm{E}-3-3$ & 22.26 & 1.3750 & & & 1.25 & 1.57 & -0.28 \\
\hline $851 \mathrm{E}-3-3$ & 22.36 & 1.3810 & & & 0.84 & 1.72 & -0.34 \\
\hline $851 \mathrm{IE}-3-3$ & 22.46 & 1.3870 & & & 0.07 & 1.69 & -0.70 \\
\hline $851 \mathrm{E}-3-3$ & 22.56 & 1.3920 & -1.05 & 2.09 & -0.06 & 1.69 & -1.27 \\
\hline $851 \mathrm{E}-3-3$ & 22.66 & 1.3980 & & & -0.51 & 1.31 & \\
\hline $851 \mathrm{IE}-3-3$ & 22.76 & 1.4030 & & & 0.15 & 1.56 & \\
\hline $851 \mathrm{E}-3-3$ & 22.86 & 1.4080 & & & 1.08 & 1.32 & -0.45 \\
\hline $851 \mathrm{E}-3-3$ & 22.96 & 1.4130 & & & -0.28 & 1.75 & -1.07 \\
\hline $851 \mathrm{E}-3-3$ & 23.06 & 1.4180 & & & 0.42 & 1.62 & -0.46 \\
\hline $851 E-3-3$ & 23.16 & 1.4220 & & & 0.61 & 1.59 & -0.79 \\
\hline $851 \mathrm{E}-3-3$ & 23.26 & 1.4270 & -1.57 & 2.41 & 0.43 & 1.33 & -1.08 \\
\hline $851 \mathrm{E}-3-3$ & 23.36 & 1.4310 & & & 0.40 & 1.30 & -0.90 \\
\hline $851 E-3-3$ & 23.46 & 1.4360 & -1.61 & 1.97 & 0.72 & 1.19 & -0.90 \\
\hline $851 \mathrm{E}-3-4$ & 23.56 & 1.4400 & & & 0.81 & 1.15 & -0.78 \\
\hline $851 \mathrm{E}-3-4$ & 23.66 & 1.4450 & & & 0.25 & 1.35 & \\
\hline $851 \mathrm{E}-3-4$ & 23.76 & 1.4490 & & & 0.39 & 1.69 & \\
\hline $851 \mathrm{E}-3-4$ & 23.86 & 1.4540 & & & 0.71 & 1.79 & \\
\hline $851 \mathrm{E}-3-4$ & 23.96 & 1.4580 & & & 0.41 & 2.05 & \\
\hline $851 \mathrm{E}-3-4$ & 24.06 & 1.4630 & & & 0.53 & 1.62 & -0.72 \\
\hline $851 \mathrm{E}-3-4$ & 24.16 & 1.4670 & & & 0.66 & 1.31 & -0.58 \\
\hline
\end{tabular}

tively small temperature range of between the eastern and western tropics (Fig. 2) and between seasons (Curry et al., 1983). However, the Site 851 N. dutertrei record varies considerably from the Site 677 benthic record, indicating that the $N$. dutertrei record is, to a large extent, a reflection of local temperature and possibly $\delta_{w}$ conditions. This observation was not predicted from our model of vertical habitat based on the modern $\delta^{18} \mathrm{O}$ of $N$. dutertrei (Fig. 2). Although $N$. dutertrei probably is a reliable indicator of thermocline-depth conditions, the fact that it calcifies within the steep subsurface seasonal thermal gradient means that only slight changes in the depth of calcification from one period to the next will have a significantly large influence on the $\delta^{18} \mathrm{O}$ of its shell.

Using Site 677 , a record that is probably influenced less by temperature than most planktonic records, as the baseline for comparison 
Table 2. Comparison of core-top $\delta^{18} \mathrm{O}$ values from tropical sites.

\begin{tabular}{|c|c|c|c|c|c|c|}
\hline Site & Latitude & Longitude & $\begin{array}{l}\text { Water } \\
\text { depth } \\
\text { (m) }\end{array}$ & G. sacculifer & N. dutertrei & G. tumida \\
\hline \multicolumn{7}{|c|}{ Eastern tropical sites: } \\
\hline ODP 851 & $3^{\circ} \mathrm{N}$ & $111^{\circ} \mathrm{W}$ & 3772 & -0.91 & 0.53 & 0.72 \\
\hline V29-144 & $0^{\circ}$ & $6^{\circ} \mathrm{E}$ & 2685 & -1.40 & -0.20 & 0.80 \\
\hline $\mathrm{V} 21-30$ & $0^{\circ}$ & $90^{\circ} \mathrm{W}$ & 617 & -1.34 & -0.48 & 0.60 \\
\hline \multirow{2}{*}{\multicolumn{7}{|c|}{ Western tropical sites: }} \\
\hline V $22-38$ & & & & -1.30 & 0.10 & -0.05 \\
\hline V28-203 & $1^{\circ} \mathrm{N}$ & $180^{\circ} \mathrm{E}$ & 3243 & -1.70 & -0.60 & -0.90 \\
\hline
\end{tabular}

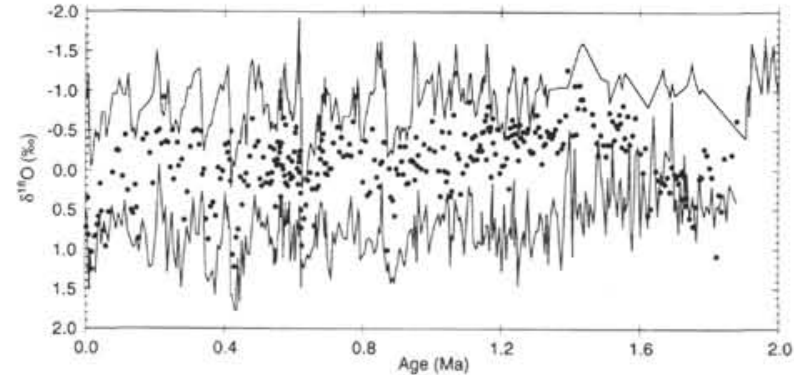

Figure 3. $\delta^{18} \mathrm{O}$ records of $G$. sacculifer (upper curve), $N$. dutertrei (solid circles), and $G$. tumida (lower curve).
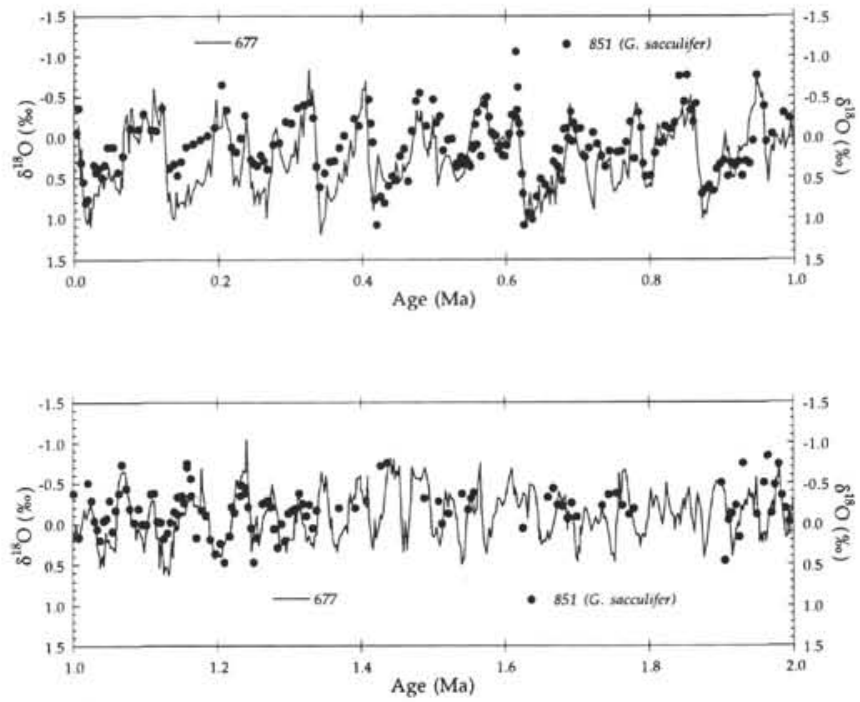

Figure 4. Normalized $\delta^{18} \mathrm{O}$ records of Site 677 benthic foraminifers of Site 851 G. sacculifer.

with the Site 851 records, the G. sacculifer record (Fig. 4) has approximately the same amplitude and general trend, the $G$. tumida record (Fig. 5) has approximately the same amplitude and lighter values between 1.4 and $1.7 \mathrm{Ma}$, and the $N$. dutertrei record (Fig. 6) has approximately the same amplitude with lighter values between 1.2 and $1.6 \mathrm{Ma}$ and heavier values between 1.6 and $1.9 \mathrm{Ma}$. The times when the $N$. dutertrei and $G$. tumida values deviate from the Site 677 values result from changes in subsurface hydrography: a shoaling or deepening of the thermocline. Essentially, the largest change in subsurface hydrography (depth of the thermocline) occurs when $N$. dutertrei and $G$. tumida change from having similar values (deeper thermocline) at 1.6 to $1.8 \mathrm{Ma}$, to having values approximately $1.0 \%$ apart during 1.5 Ma up to recent time (shallower thermocline).
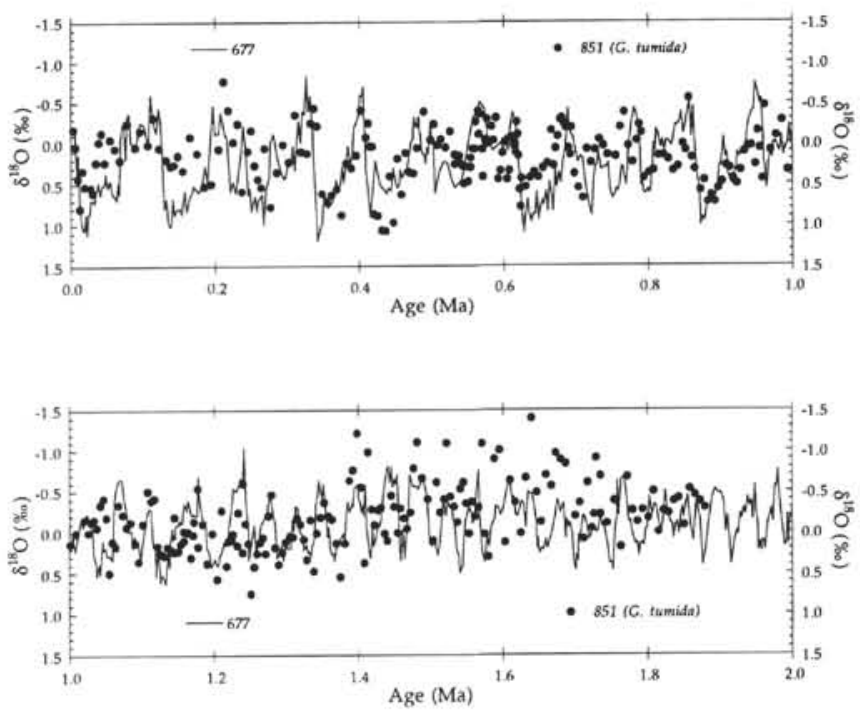

Figure 5. Normalized $\delta^{18} \mathrm{O}$ records of Site 677 benthic foraminifers of Site 851 G. tumida.

The degree to which the $\delta^{18} \mathrm{O}$ records at Sites 851 and 677 co-vary can be determined by cross-spectral analysis (Figs. 7A and 7B). Between 0.0 and $0.78 \mathrm{Ma}$, a significant portion of the variance for both records occurs at $100,41,23$, and $19 \mathrm{k} . \mathrm{y}$. The two records are coherent and in phase at 100,41 , and $23 \mathrm{k} . \mathrm{y}$. The same is true for 0.78 to $1.36 \mathrm{Ma}$; however, in Site 677 a larger portion of the total variance occurs at 41 k.y. relative to the Site 851 record. In addition, while the Site 677 record has more variance at 41 relative to 100 k.y., as expected for records of variations in ice volume from this time period (Ruddiman and Raymo, 1988), that at Site 851 does not. Variance at the precessional frequencies is always relatively low as expected from a $\delta^{18} \mathrm{O}$ record that primarily reflects global ice volume.

\section{Carbon Isotopes}

Carbon isotopic values of $G$. sacculifer are generally higher than the carbon isotopic values of $N$. dutertrei and $G$. tumida. The $G$. sacculifer and $G$. tumida $\delta^{13} \mathrm{C}$ curves are roughly parallel to each other (Fig. 8) and to the benthic $\delta^{13} \mathrm{C}$ record from Site 677 (Figs. 9 and $10)$, for the period from $1.9 \mathrm{Ma}$ to the present, suggesting that they represent global or Pacific-wide fluctuations in $\delta^{13} \mathrm{C}$ of seawater. The $N$. dutertrei data appear to be more variable (Fig. 11) than the $G$. sacculifer and $G$. tumida data, although several of the general features, such as the low at $0.9 \mathrm{Ma}$ (Fig. 8), have been reproduced by $N$. dutertrei. G. tumida and $N$. dutertrei calcify within the subsurface temperature and nutrient gradients, where small changes in the depth of calcification can influence their $\delta^{13} \mathrm{C}$ signature. In particular, $N$. dutertrei calcifies in the steepest part of the thermocline, which is coincident with steep nutrient and $\delta^{13} \mathrm{C}$ of seawater gradients. Thus, 

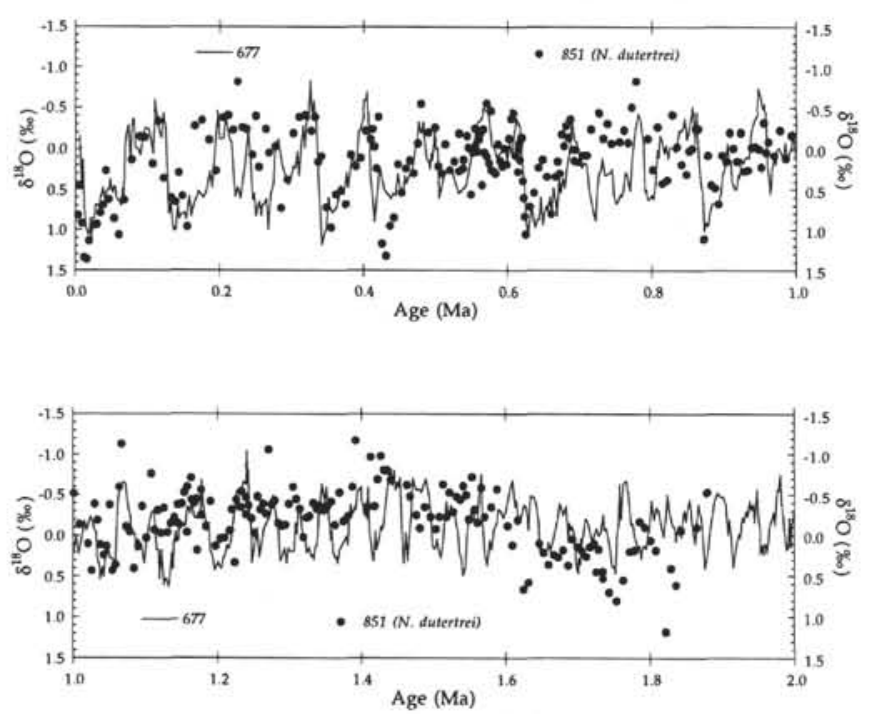

Figure 6. Normalized $\delta^{18} \mathrm{O}$ records of Site 677 benthic foraminifers of Site 851 N. dutertrei.
A
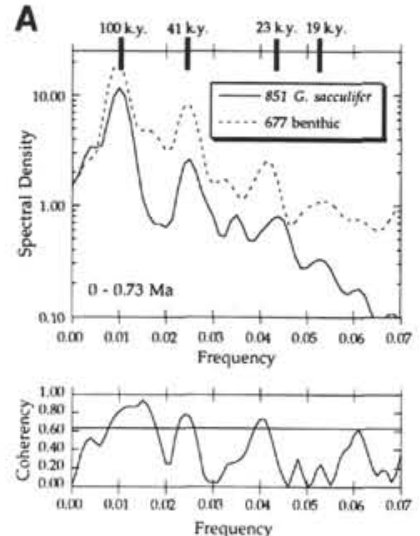

B
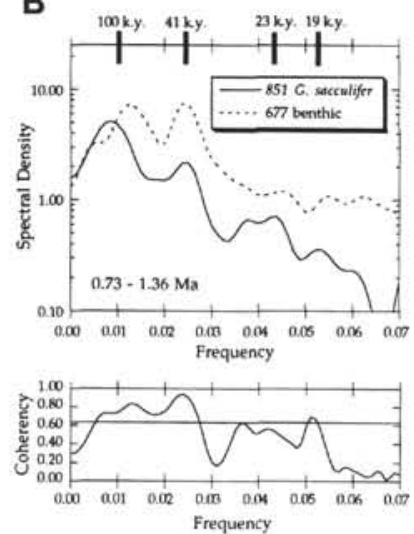

Figure 7. Cross-spectral analysis of Site 851 G. sacculifer and Site 677 benthic $\delta^{18} \mathrm{O}$ for two different time periods.

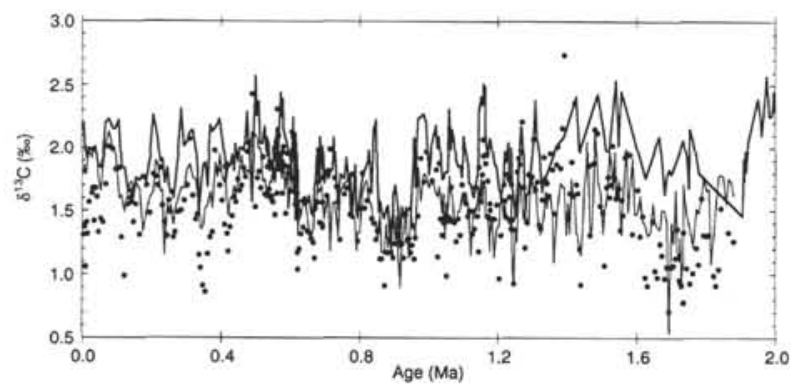

Figure $8 . \delta^{13} \mathrm{C}$ records of $G$. sacculifer (upper curve), $N$. dutertrei (solid circles), and G. tumida (lower curve).

it is not surprising that their records, particularly that of $N$. dutertrei would be different in detail from the Site $677 \delta^{13} \mathrm{C}$ signal or from the "nutrient-depleted" signal of $G$. sacculifer.

The absolute values of the three species are within about $0.5 \%$ of each other, with $G$. tumida and $N$. dutertrei having nearly the same values even though $N$. dutertrei clearly grows at slightly warmer temperatures, and presumably in waters with higher $\delta^{13} \mathrm{C}$ values, than
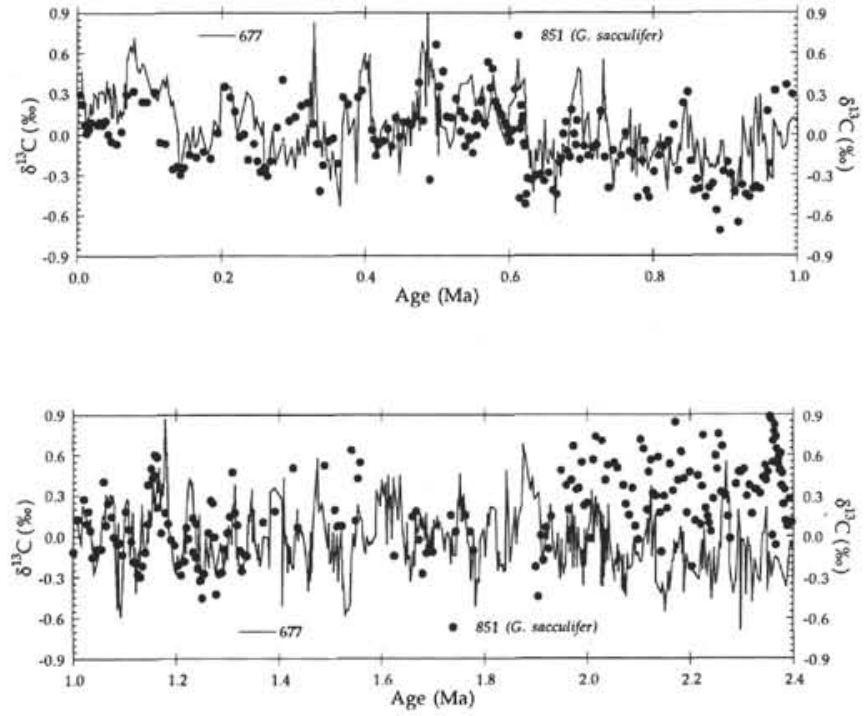

Figure 9. Normalized $\delta^{13} \mathrm{C}$ records of Site 677 benthic foraminifers of Site 851 G. sacculifer.
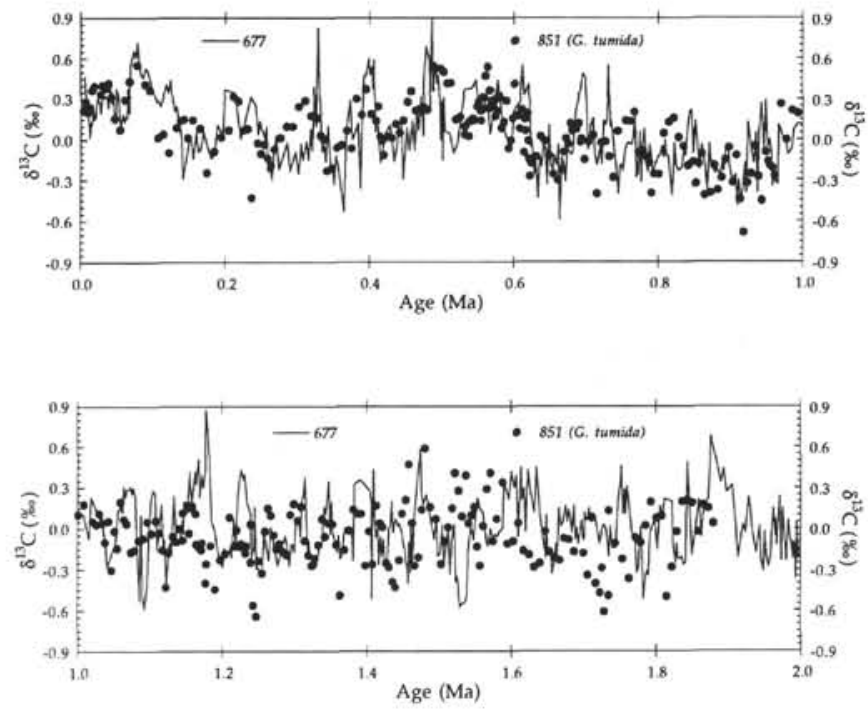

Figure 10. Normalized $\delta^{13} \mathrm{C}$ records of Site 677 benthic foraminifers of Site 851 G. tumida.

G. tumida. This can be explained by the vital effects of each species at this size range; $G$. tumida generally calcifies with $\delta^{13} \mathrm{C} 1.0 \%$ heavier than seawater values, and $N$. dutertrei generally calcifies with $\delta^{13} \mathrm{C} 0.5 \%$ heavier than seawater values (Ravelo, 1991). As with the $\delta^{18} \mathrm{O}$ records, there may be a notable shift at about $1.5 \mathrm{Ma}$. The $\delta^{13} \mathrm{C}$ data, however, appears to be too noisy to assess whether the $1.5 \mathrm{Ma}$ shift represents a change in the depth of the thermocline. The expected magnitude of $\delta^{13} \mathrm{C}$ variations caused by the movement of the thermocline and nutricline is relatively small, compared with the mean global variations in $\delta^{13} \mathrm{C}$. Therefore, $\delta^{18} \mathrm{O}$ is a more reliable indicator of changes in thermocline depth.

In the oldest part of the record (only G. sacculifer) normalized $\delta^{13} \mathrm{C}$ values of Sites 851 and 677 deviate from each other, with the planktonic values being high relative to the benthic values (Fig. 9). This is more clearly shown in a scatter plot (Fig. 12), where the carbon isotope data from $G$. sacculifer and from benthic foraminifers from Site 677 has been plotted to compare the benthic-planktonic differ- 

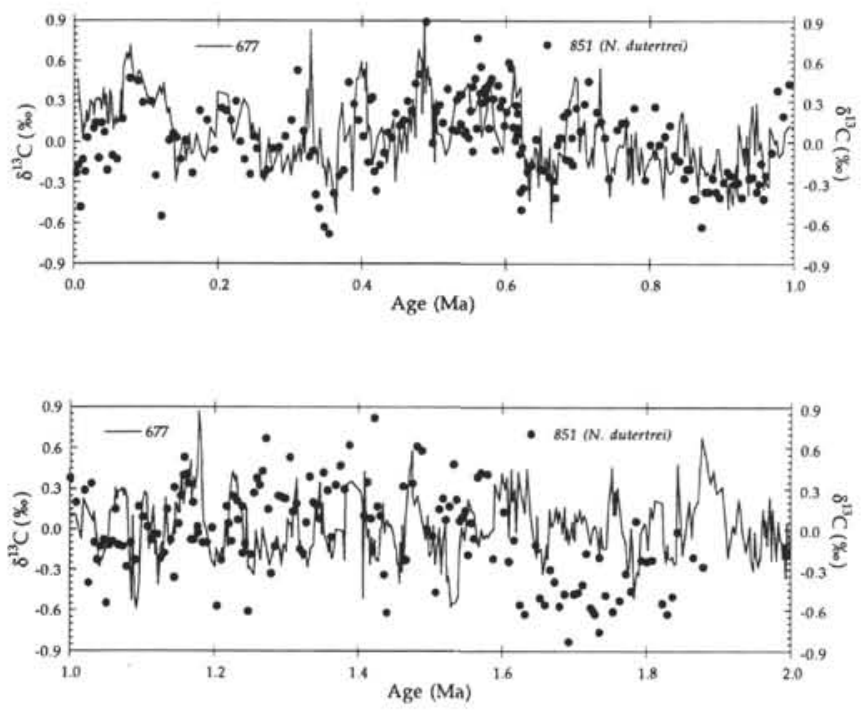

Figure 11. Normalized $\delta^{13} \mathrm{C}$ records of Site 677 benthic foraminifers of Site $851 N$. dutertrei.

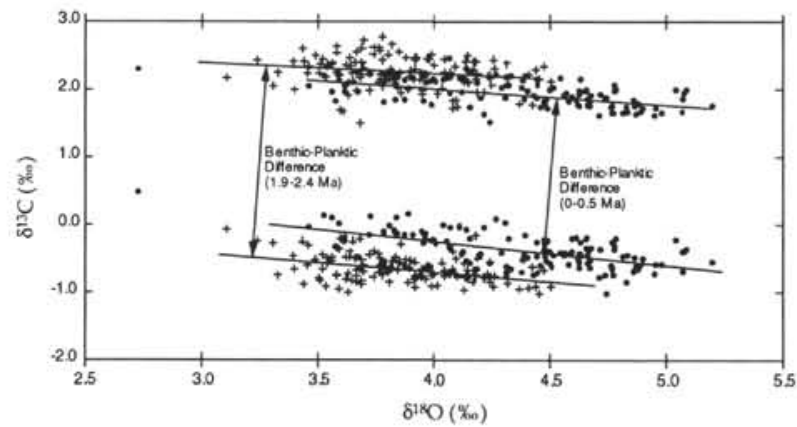

Figure 12. Comparison of Site 677 benthic foraminifer (clusters of lower $\delta^{13} \mathrm{C}$ values) and Site 851 G. sacculifer (clusters of higher $\delta^{13} \mathrm{C}$ values) data for two time slices: 0 to $0.5 \mathrm{Ma}$ (solid symbols) and 1.9 to $2.4 \mathrm{Ma}$ (crosses). Note that planktonic-benthic differences are larger, primarily because of the lighter $\delta^{13} \mathrm{C}$ values of Site 677 benthic foraminifers, for the older time slice.

ence for two time slices. The carbon isotope data has been plotted vs. oxygen isotopes of Site 677 to see how the benthic-planktonic difference varies as ice volume changes within each of the two time slices. For the time period between 0 and $0.5 \mathrm{Ma}$, the benthic-planktonic difference in $\Delta \delta^{13} \mathrm{C}$ is about $2.0 \%$ across a range of oxygen isotope values (ice volumes). For the period between 1.9 and $2.4 \mathrm{Ma}$, the benthic-planktonic $\Delta \delta^{13} \mathrm{C}$ difference is larger. The shift in $\Delta \delta^{13} \mathrm{C}$ between these two time slices is caused primarily by changes in the benthic record from lower values in the late Pliocene to higher values after about $1.9 \mathrm{Ma}$.

\section{GLACIAL/INTERGLACIAL VARIATIONS Oxygen Isotopes}

A closer look (Fig. 13) at the most recent glacial stages indicates that glacials are possibly periods that had a deeper thermocline $(G$. tumida-G. sacculifer difference is less than the mean). According to our model (described earlier), when the G. tumida-G. sacculifer difference was small during the glacials, the thermocline was deep, such that the two species calcified at nearly the same temperatures relative to interglacial periods. However, our model also predicts that the difference between $G$. tumida and $N$. dutertrei should also be

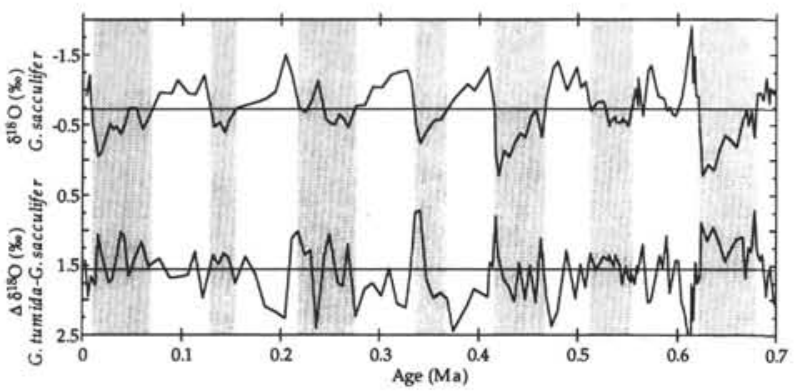

Figure 13. Interglacial/glacial variations in ice volume $\left(\delta^{18} \mathrm{O}\right.$ of $G$. sacculifer $)$ compared with variations in the $\Delta \delta^{18} \mathrm{O}$ between $G$. sacculifer and $G$. tumida. Shaded areas are periods of greater than mean $\delta^{18} \mathrm{O}$ values of $G$. sacculifer.
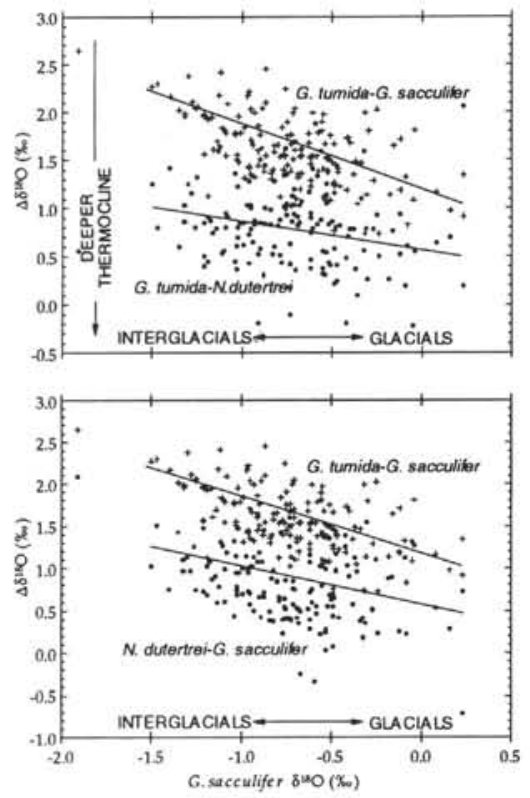

Figure 14. Scatter plots comparing species $\delta^{18} \mathrm{O}$ differences from Site 851 during the last $0.78 \mathrm{Ma}$.

smaller as the thermocline deepens. In Figure 14, it is clear that while the $G$. tumida-G. sacculifer difference is weakly correlated to ice volume $\left(\delta^{18} \mathrm{O}\right.$ of $G$. sacculifer $)$ the $G$. tumida-N. dutertrei difference is not related so directly. Thus, the general correlation between the $G$. tumida-N. dutertrei difference and ice volume probably results from both changes in the thermocline depth and changes in the calcification temperature of $G$. sacculifer (SSTs were cooler during glacial stages, creating a smaller $G$. tumida-G. sacculifer difference). While there may be changes in thermocline depth on a glacial-to-interglacial time scale, they are apparently masked in part by changes in SSTs that have been recorded by $G$. sacculifer. Changes in SST also should affect the $N$. dutertrei-G. sacculifer difference; a lower $N$. dutertrei-G. sacculifer difference is expected for periods of cooler SST, as was observed (Fig. 14) for glacial periods. Another way of analyzing whether the relative differences in $\delta^{18} \mathrm{O}$ data between the three species results from changes in thermocline depth or SST is to perform cross-spectral analysis on the $G$. tumida-N. dutertrei difference and the $G$. tumida-G. sacculifer difference. We expect that these two $\Delta \delta^{18} \mathrm{O}$ records would co-vary if they were driven by changes in the thermocline depth. For example, a deeper thermocline would result in smaller values for both $\Delta \delta^{18} \mathrm{O}$ records. A change in SST would affect the $G$. tumida $-G$. sacculifer $\Delta \delta^{18} \mathrm{O}$ difference, but not the $G$. tumida$N$. dutertrei $\Delta \delta^{18} \mathrm{O}$ difference. In Figure 15, it is clear that these two $\Delta \delta^{18} \mathrm{O}$ records co-vary at the $19-\mathrm{k} . y$. period only. Thus, both the cross- 

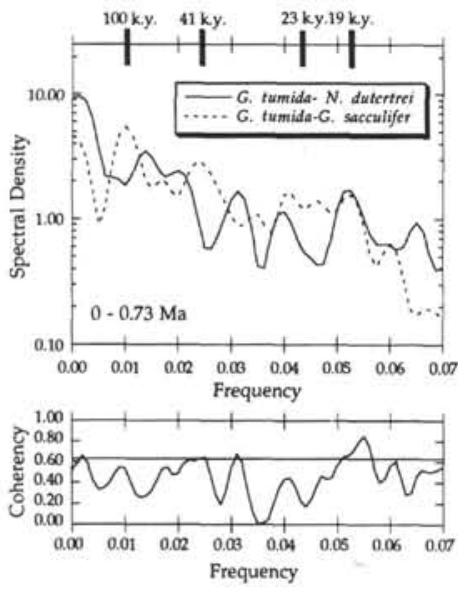

Figure 15. Cross-spectral analysis of $\delta^{18} \mathrm{O}$ differences between $G$. tumida and $G$. sacculifer and between $G$. tumida and $N$. dutertrei. Notice significant coherency (above $80 \%$ level) for the 19 k.y. period.

spectral analysis and the simple relationships shown in the scatter plot suggest that SST variations, not just changes in thermocline depth, must have an influence on the $G$. tumida-G. sacculifer $\Delta \delta^{18} \mathrm{O}$ difference on glacial/interglacial time scales.

\section{Carbon Isotopes}

The $\delta^{13} \mathrm{C}$ values of all three species analyzed over the last 700,000 $\mathrm{yr}$ are generally low during the glacials and higher during interglacials (Fig. 16). The shaded regions are periods when the $\delta^{18} \mathrm{O}$ of $G$. sacculifer is higher than the mean, and on first-order, these are times when the $\delta^{13} \mathrm{C}$ values are low for all three species. However, clearly, significant differences exist between the three species. According to our model of the vertical stratification of species, $N$. dutertrei is the best indicator of thermocline conditions, and the N. dutertrei-G. sacculifer difference should represent how the thermocline $\delta^{13} \mathrm{C}$ properties changed relative to the surface water where $G$. sacculifer calcified. Figure 17 shows that the $N$. dutertrei-G. sacculifer $\delta^{13} \mathrm{C}$ difference does not appear to vary at the same low frequency (100 k.y.) period as $\delta^{18} \mathrm{O}$ and $\delta^{13} \mathrm{C}$. In fact, while the $\delta^{13} \mathrm{C}$ of $N$. dutertrei (and the other species measured) varies predominantly at a period of $100 \mathrm{k} . \mathrm{y}$., the variance of the $N$. dutertrei-G. sacculifer $\delta^{13} \mathrm{C}$ difference is high and coherent with changes in ice volume at a period of 40 k.y. (Fig. 17). The most likely explanation is that the carbon isotopic composition of the source of upwelling thermocline water at this location has changed through time. Because the benthic $\delta^{13} \mathrm{C}$ record from Site 677 is not coherent with the $N$. dutertrei-G. sacculifer $\delta^{13} \mathrm{C}$ difference from Site 851 at most frequencies, it is most likely that the source of thermocline waters at Site 851 is intermediate water. This would have to be verified by a comparison of a Pacific Intermediate Water record with the $N$. dutertrei-G. sacculifer $\delta^{13} \mathrm{C}$ difference record generated in this study.

\section{DISCUSSION}

\section{Deeper Thermocline during the Late Pliocene and Early Pleistocene}

In the modern ocean at the location of Site 851, variations in thermocline depth seasonally correspond to seasonal changes in wind field and interannually correspond to changes in the annual mean wind field. Seasonal and interannual variations in modern tropical circulation may provide some insight into the mechanism for the observed thermocline changes that occurred from the late Pliocene through the Pleistocene. The largest observed change in the depth of the thermocline was the transition from a deeper thermocline during the period 1.5 to $1.8 \mathrm{Ma}$ to a shallower thermocline from $1.5 \mathrm{Ma}$ to today (Fig. 3).

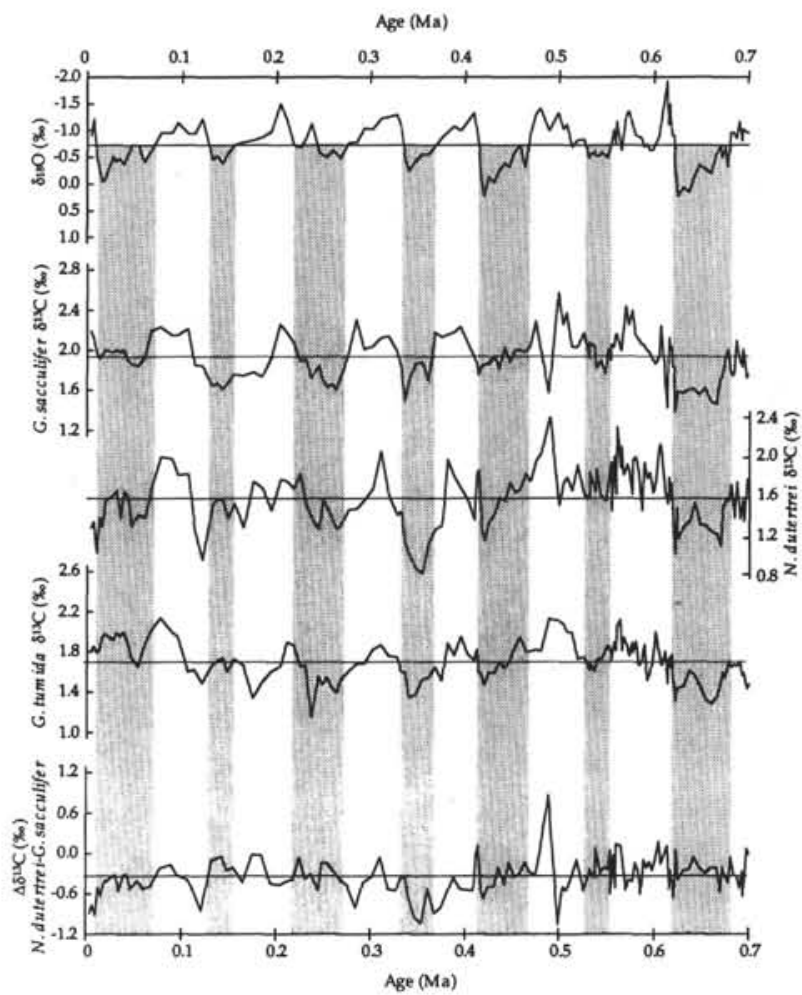

Figure 16. Interglacial/glacial variations in ice volume $\left(\delta^{18} \mathrm{O}\right.$ of $G$. sacculifer $)$ and in "global" carbon isotopic composition $\left(\delta^{13} \mathrm{C}\right.$ of $G$. sacculifer, G. tumida and $N$. dutertrei) compared with variations in subsurface chemistry $\left(\delta^{13} \mathrm{C}\right.$ of $N$. dutertrei) relative to surface chemistry $\left(\delta^{13} \mathrm{C}\right.$ of $G$. sacculifer $)$. Shaded time periods represent periods when ice volume was higher than mean.

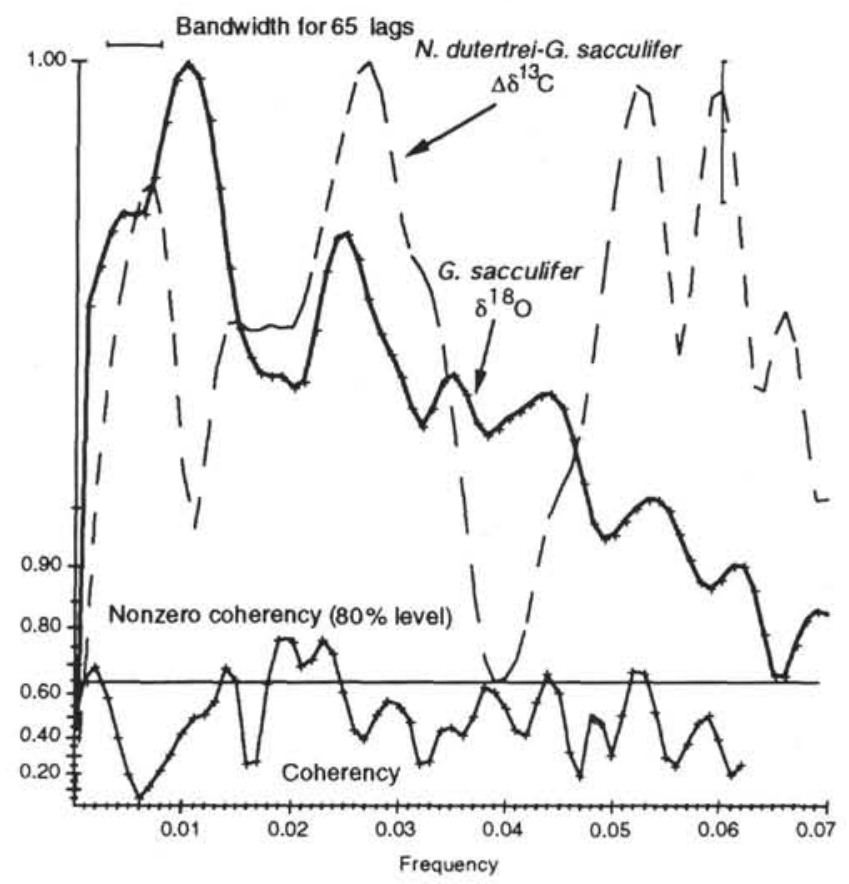

Figure 17. Cross-spectral analysis of $\Delta \delta^{13} \mathrm{C}$ between $N$. dutertrei and $G$. sacculifer (dashed line) and $\delta^{18} \mathrm{O}$ of G. sacculifer (ice volume indicator) (line with crosses). Coherency is the lower solid line with crosses. 
At the location of Site 851 today, $~ 50$-m seasonal fluctuations occur in the depth of the thermocline from changes in the seasonally varying wind-driven surface ocean circulation (Fig. 1). In August through December, the southeast trade winds, the SEC, and the ECC are very strong. While the SEC advects cool water from the southeast into the region, the ECC carries warm water from the west, depressing the thermocline along its path. The EUC is relatively weak during this period (Halpern and Weisberg, 1989), with the trans-Pacific east-towest dipping slope of the thermocline at a maximum (Meyers, 1979). From February through April, the southeasterly trade winds are weaker and the ITCZ is in its southernmost position, so that the winds over Site 851 and the equator are at a minimum. From March through May, the EUC is strongest (Halpern and Weisberg, 1989), the east-towest slope of the thermocline is minimized, and the thermocline is relatively shallow (Meyers, 1979). Using the seasonal response of the thermocline to the wind field as an analogy for what changes may have occurred, it is possible that the deeper mean position of the thermocline during 1.5 to $1.8 \mathrm{Ma}$ may result from a number of different factors. Because the depth of the thermocline at Site 851 is deepest during the season of strongest winds and influence from the ECC, the 1.5- to 1.8-Ma trade winds may have been generally stronger with the influence of the ECC being stronger. Alternatively, the entire mean position of the ITCZ may have been shifted to the south, so that the ECC more directly influenced the hydrography at Site 851 (presently Site 851 is at the far southern edge of the ECC). Today, the season of minimum thermocline depth is coincident with the season of maximum EUC. Therefore, a third alternative may be that the mean winds were weaker, creating a reduced trans-Pacific pressure gradient and therefore a reduced EUC.

Interannual variations (El Niños) in tropical Pacific Ocean circulation, the strength of the EUC, and the depth of the thermocline have been extensively studied in the present and in the historical past (e.g., Halpern, 1987; Enfield, 1989; and Philander, 1990). During El Niños, the eastern tropical Pacific has anomalously weak easterly winds (sometimes westerly winds develop), a deep thermocline, and warm SSTs. In simple terms, El Niños represent times during which air-sea interactions perpetuate a situation of reduced east-to-west flow and reduced EUC flow, inducing a dramatic change in the surface and subsurface conditions across the entire basin. El Niños have been linked to a reversal or weakening of the normal high (e.g., in the southeast Pacific) to low (e.g., at Indonesia) pressure flow that drives Walker circulation, whose lower limbs are the trade winds. A relatively deep thermocline at 1.5 to $1.8 \mathrm{Ma}$ may represent a situation where El Niño-type circulation occurred more frequently because of a less stable "normal" climate pattern. The mechanism for more frequent El Niños might be changes in the strength of the low and high pressure zones caused by changes in continental conditions or changes in the extratropical conditions. At present we do not know if more severe or frequent El Niños would be likely should the mean normal circulation consist of stronger or weaker trade winds. On one hand, generally weaker trade winds might generate permanent conditions more like El Niños. On the other hand, it is possible that stronger trade winds would pre-condition the tropics for stronger or more frequent El Niños.

In sum, the deeper thermocline of 1.5 to $1.8 \mathrm{Ma}$ may have resulted from a number of different factors, including stronger winds, weaker winds, or shifts in the position of the ITCZ. This unsatisfactory finding suggests that more research will have to be done to see what the thermocline depth is at other locations during this time period. A more complete map pattern of thermocline depth in this region would certainly constrain interpretations.

\section{General Carbon Isotope Trends}

As described earlier, all three species measured from Site 851 display the same general $\delta^{13} \mathrm{C}$ maxima and minima as the Site 677 benthic record down to the level of about $1.5 \mathrm{Ma}$ when, according to $\delta^{18} \mathrm{O}$ records, the most drastic subsurface hydrographic changes occur. From 1.5 to $1.8 \mathrm{Ma}$, the deviations of the Site 851 G. tumida (Fig. 10) and $N$. dutertrei (Fig. 11) records from the Site 677 benthic record are not accompanied by deviation of the Site 851 G. sacculifer (Fig. 9) record from the Site 677 benthic record. This supports the hypothesis that subsurface (local) hydrographic changes influence the $\delta^{13} \mathrm{C}$ records of these two subsurface planktonic species. Younger than $1.5 \mathrm{Ma}$, the parallel trends of the three planktonic records from Site 851 and the benthic record from Site 677 suggest that the $\delta^{13} \mathrm{C}$ variations are global. Because variations occur on a time scale having less than the residence time of carbon $(\sim 150,000 \mathrm{yr})$, these probably represent changes in the partitioning of carbon between temporary reservoirs (e.g., terrestrial biomass and ocean). Visually, the most drastic transitions and excursions in $\delta^{13} \mathrm{C}$, such as the ones from low to high values at around 0.85 and $0.60 \mathrm{Ma}$, do not seem to have occurred at a regular frequency.

The most pronounced deviation of the $G$. sacculifer record from the normalized Site 677 record occurred in the interval between about 1.9 and 2.4 Ma. During this interval, the $\delta^{13} \mathrm{C}$ of $\mathrm{G}$. sacculifer has been enriched relative to the benthic $\delta^{13} \mathrm{C}$ values. In Figure 10, clearly, the mean value of the deep waters during the older time slice has been depleted, while the surface waters have been slightly enriched, relative to the younger time slice. This is consistent with earlier findings (Curry and Miller, 1989; Raymo et al., 1990; Raymo et al., 1992) that the deep-water chemistry in the Pacific Ocean has lower $\delta^{13} \mathrm{C}$ values that represent higher nutrient and carbon contents of the Pacific during the late Pliocene. The planktonic record does not follow the deep Pacific trend, as it does throughout the Pleistocene, suggesting that there may be local hydrographic changes within the eastern tropical Pacific, such that surface waters are more nutrient-depleted relative to deep waters and relative to younger time periods. Future measurements of $G$. tumida and $N$. dutertrei will help to constrain the regional hydrographic changes responsible for this decoupling between the surface and deep waters. In today's ocean, the surface waters of the eastern tropical Pacific are linked to deeper waters via coastal and divergent upwelling, although Toggweiler et al. (1991) showed that these upwelled waters are primarily intermediate in origin. During the late Pliocene, the relatively high $\delta^{13} \mathrm{C}$ surfacewater values may have resulted from higher nutrient utilization by plankton or less upwelling of intermediate and deep Pacific waters. Alternatively, the source of upwelled waters may have been different. In any case, it will be important in the future to look at clues for regional hydrographic changes during this time.

\section{Glacial/Interglacial Trends}

As discussed above, the observed correlation between ice volume (represented by $G$. sacculifer $\delta^{18} \mathrm{O}$ ) and $\Delta \delta^{18} \mathrm{O}$ (Fig. 13) to a large extent reflects decreases in SST during glacial periods. $\Delta \delta^{18} \mathrm{O}$ can be used as an estimate of interspecies temperature differences because the global ice volume effect on $\delta^{18} \mathrm{O}$ is canceled out when the difference is taken. This method also assumes that local $\delta^{18} \mathrm{O}$ of seawater changes (from local variations in the hydrologic cycle) are canceled out as well. The range in $\Delta \delta^{18} \mathrm{O}$ (G. tumida-G. sacculifer; Fig. 14) is roughly $1.9 \%$ to $2.4 \%$ during interglacial periods and around $1.0 \%$ to $1.5 \%$ during glacial periods whereas the range in $\Delta \delta^{18} \mathrm{O}(N$. dutertrei-G. sacculifer; Fig. 14) is about $1.0 \%$ to $1.5 \%$ during interglacial periods and $\sim 0.25 \%$ and $1.0 \%$ during glacial periods. Using the paleotemperature equation of Epstein et al. (1953), this amounts to a temperature difference between $G$. tumida and $G$. sacculifer of about $9^{\circ}$ and $5^{\circ} \mathrm{C}$ during interglacial and glacial periods, respectively, and a temperature difference between $N$. dutertrei and $G$. sacculifer of about $5^{\circ}$ and $3^{\circ} \mathrm{C}$ during interglacial and glacial periods, respectively. Since the $\Delta \delta^{18} \mathrm{O}$ of $N$. dutertrei-G. sacculifer over the last $0.78 \mathrm{Ma}$ result from, in large part, SST changes rather then thermocline changes, this rough calculation implies that SSTs were approximately $2^{\circ} \mathrm{C}$ cooler during glacial periods at Site 851 . The $\Delta \delta^{18} \mathrm{O}$ of $G$. tumida-G. sacculifer decreases by $4^{\circ} \mathrm{C}$ during glacials, $2^{\circ} \mathrm{C}$ of this is the result of cooler 
SSTs, and $2^{\circ}$ is the result of warmer $G$. tumida calcification, implying that the thermocline is slightly deeper during glacial periods. Crossspectral analysis (Fig. 15) of the $\Delta \delta^{18} \mathrm{O}$ of $G$. tumida-G. sacculifer and of $\Delta \delta^{18} \mathrm{O}$ of $G$. tumida-N. dutertrei indicates that these two difference records are coherent only at 19 k.y., not at any of the other periods at which they vary. Because the $\Delta \delta^{18} \mathrm{O}$ of $G$. tumida- $N$. dutertrei is not affected by SST changes, it can be used as an indicator of thermocline depth, which varies at $31, \sim 55$ and 19 k.y. (Fig. 15). The 31 k.y. period, found in records of divergence, has been explained as a nonlinear response to orbital forcing, with possibly some acting resonance phenomenon (Pisias and Rea, 1988). The $\Delta \delta^{18} \mathrm{O}$ of $G$. tumida $-G$ sacculifer is a combination of SST and thermocline changes and varies at 100,41, 23 , and $19 \mathrm{k} . \mathrm{y}$. The difference in the spectra of these two different $\Delta \delta^{18} \mathrm{O}$ records indicates SST variations are somewhat decoupled from thermocline variations.

Because the amplitude of the surface water $\delta^{13} \mathrm{C}$ isotope changes are close to what the 'global' changes are (using Site 677 as a "global" record), the cool local SSTs during glacial periods do not appear to have been accompanied by any significant local $\delta^{13} \mathrm{C}$ changes. Thus, there may simply be changes in radiative heating or evaporative cooling of the surface at this location because changes in the horizontal or vertical advection of cool, nutrient-rich waters are unlikely without a significant change in the $\delta^{13} \mathrm{C}$. In addition, the deeper thermocline during glacial periods implies less advection of cool waters. This interpretation is in contrast to the idea that glacial events were periods of more intense upwelling; however, Site 851 can be used only to monitor the hydrographic changes near the SEC/ECC boundary, not the equatorial upwelling system in general. If the cooler SSTs are the result of more intense upwelling of cool waters to the surface, then the absence of a corresponding $\delta^{13} \mathrm{C}$ signal may be explained by the insensitivity of $\delta^{13} \mathrm{C}$ to changes in upwelling and productivity strength because of the stronger, higher-amplitude effect of global carbon isotopic changes that mask simultaneous changes in local surface nutrient levels. However, when the $\Delta \delta^{13} \mathrm{C}$ is calculated between $N$. dutertrei and G. sacculifer as a way of investigating local changes in the subsurface nutrient content relative to the surface, variations generally are not synchronous with glacial/interglacial events (Fig. 16). The absence of a local change in $\delta^{13} \mathrm{C}$ that corresponds to local temperature decreases, and the fact that the thermocline may be slightly deeper, strongly suggests that stronger upwelling and productivity did not occur at Site 851 during glacial events. As with the interpretation of the longer changes in time scale (e.g., the deep thermocline period at 1.5-1.8 Ma), the deepening of the thermocline at Site 851 during glacial events can be explained by a wide range of scenarios involving wind field changes. A future challenge will be to do the same type of multispecies analyses at other locations in the eastern tropical Pacific to map out the regional changes in the depth of the thermocline and SSTs to resolve changes in the glacial wind field.

\section{SUMMARY}

Core-top data suggest that $G$. sacculifer, G. tumida, and $N$. dutertrei can be used to monitor thermocline depth changes in the tropics with the difference between $G$. tumida and $G$. sacculifer and that between $G$. tumida and $N$. dutertrei, which decrease when the thermocline deepens. The general trends of the oxygen isotopic values measured using these three species suggest a change from a deeper thermocline before 1.5 Ma to a shallower one after 1.5 Ma. A deeper thermocline might have resulted from an increase in the ECC or a decrease in the EUC. It is not clear whether these thermocline depth changes have been forced by stronger or weaker trade winds, or by a shift southward in the ITCZ. Carbon isotopic values generally follow the benthic Pacific carbon isotopic values, suggesting that the main cause of carbon isotopic variations are global. Only in the interval of 1.9 to 2.4 Ma do the carbon isotope curves deviate significantly from each other as the planktonic values are higher, and benthic values are lower, then the period younger than $1.9 \mathrm{Ma}$.
In the most recent period, $0.78 \mathrm{Ma}$, the thermocline was deeper, and SST was reduced during past glacial events. Again, the mechanism for these changes is not understood because of the complicated nature of the wind-forced circulation at this location. Variance in the carbon isotopic composition, and possibly nutrient levels of upwelling water, have been concentrated at higher frequencies than fluctuations in ice volume.

A greater spatial resolution will be needed to reconstruct the three-dimensional shape of the thermocline. Combined with results of wind field changes from eolian studies and modeling, thermocline changes might be more accurately interpreted.

\section{ACKNOWLEDGMENTS}

We thank Linda Koch, Jennifer Compton, Chris Hutcherson, and Ronnie Podilla for technical help; Terri Hagelberg for work on the GRAPE composite used in some of the age models; John Farrell and Bill Chaisson for E-mail conversation about foraminifers; and Maureen Raymo and Jim Wright for their comments and criticisms. Special thanks to Mike Hall for isotopic analyses at the University of Cambridge, and Eystein Jansen, Odd Hansen, and Rune Søraas for isotopic analyses at the University of Bergen. Thanks also to the Ocean Drilling Program and JOIDES/USSAC for supporting this research financially and for support during participation in Leg 138.

\section{REFERENCES}

Adelseck, C.G., Jr., and Anderson, T.F., 1978. The late Pleistocene record of productivity fluctuations in the eastern equatorial Pacific Ocean. Geology, 6:388-391.

Bé, A.W.H., 1982. Biology of planktonic foraminifera in Buzas. In Broadhead, T.W. (Ed.), Foraminifera - Notes for a Short Course. Univ. Tenn. Stud. Geol., 6:51-89.

Bé, A.W.H., Bishop, J.K.B., Swerdlove, M.S., and Gardner, W.D., 1985. Standing stock, vertical distribution and flux of planktonic foraminifera in the Panama Basin. Mar. Micropaleontol., 9:307-333.

Berger, W.H., 1973. Deep-sea carbonates: Pleistocene dissolution cycles. J. Foraminiferal Res., 3:187-195.

Berger, W.H., Finkel, R.C., and Killingley, J.S., 1983. Glacial-Holocene transition in deep-sea sediments: manganese-spike in the east-equatorial Pacific. Nature, 303:231-233.

Boyle, E.A., 1983. Chemical accumulation variations under the Peru Current during the past 130,000 years. J. Geophys. Res., 88:7667-7680.

Chavez, F.P., Buck, K.R., and Barber, R.T., 1990. Phytoplankton taxa in relation to primary production in the equatorial pacific.Deep-Sea Res. Part A, 37:1733-1752.

Chuey, J.M., Rea, D.K., and Pisias, N.G., 1987. Late Pleistocene paleoclimatology of the central Equatorial Pacific: a quantitative record of eolian and carbonate deposition. Quat. Res., 28:323-339.

Curry, W.B., and Miller, K.G., 1989. Oxygen and carbon isotopic variation in Pliocene benthic foraminifers of the equatorial Atlantic. In Ruddiman, W., Sarnthein, M., et al., Proc. ODP, Sci. Results, 108: College Station, TX (Ocean Drilling Program), 157-166.

Curry, W.B., Thunell, R.C., and Honjo, S., 1983. Seasonal changes in the isotopic composition of planktonic foraminifera collected in Panama Basin sediment traps. Earth Planet. Sci. Lett., 64:33-43.

Duncan, R.A., and Clague, D.A., 1985. Pacific plate motion recorded by linear volcanic chains. In Nairn, A.E.M., Stehli, F.G., and Uyeda, S. (Eds.), The Ocean Basins and Margins (Vol. 7A): The Pacific Ocean: New York (Plenum), 89-121.

Durazzi, J.I., 1981. Stable isotope studies of planktonic foraminifera in North Atlantic core tops. Palaeogeogr., Palaeoclimatol., Palaeoecol., 33:157172.

Emiliani, C., 1954. Depth habitats of some species of pelagic foraminifera as indicated by oxygen isotope ratios. Am. J. Sci., 252:149-158. 1971. Depth habitats of growth stages of pelagic foraminifera. Science, 173:1122-1124.

\footnotetext{
- Abbreviations for names of organizations and publication titles in ODP reference lists follow the style given in Chemical Abstracts Service Source Index (published by
} American Chemical Society). 
Enfield, D.B., 1989. El Niño-past and present. Rev. Geophys., 27:159-187.

Epstein, S., Buchsbaum, S.R., Lowenstam, H.A., and Urey, H.C., 1953. Revised carbonate-water isotopic temperature scale. Geol. Soc. Am. Bull., 64:1315-1326.

Fairbanks, R.G., Sverdlove, M., Free, R., Wiebe, P.H., and Bé, A.W.H., 1982. Vertical distribution and isotopic fractionation of living planktonic foraminifera from the Panama Basin. Nature, 298:841-844.

Farrell, J.W., and Prell, W.L., 1989. Climatic change and $\mathrm{CaCO}_{3}$ preservation: an 800,000 year bathymetric reconstruction from the central equatorial Pacific Ocean. Paleoceanography, 4:447-466.

Ganssen, G., and Sarnthein, M., 1983. Stable-isotope composition of foraminifers: the surface and bottom water record of coastal upwelling. In Suess, E., and Thiede, J. (Eds.), Coastal Upwelling, Its Sediment Record. New York (Plenum), 10A:99-121.

Gates, W.L., 1976. The numerical simulation of ice-age climate with a general circulation model. J. Atmos. Sci., 33:1844-1873.

Halpern, D., 1987. Observations of annual and El Niño thermal and flow variations at $0^{\circ}, 110^{\circ} \mathrm{W}$ and $0^{\circ}, 95^{\circ} \mathrm{W}$ during $1980-1985$. J. Geophys. Res., 92:8197-8212.

Halpern, D., and Weisberg, R., 1989. Upper ocean thermal and flow fields at $0^{\circ}, 28^{\circ} \mathrm{W}$ (Atlantic) and $0^{\circ}, 140^{\circ} \mathrm{W}$ (Pacific) during 1983-1985. Deep-Sea Res. Part A, 36:407-418.

Janecek, T.R., and Rea, D.K., 1985. Quaternary fluctuation in the Northern Hemisphere trade winds and westeries. Quat. Res. (N.Y.), 24:150-163.

Jansen, E., Bleil, U., Henrich, R., Kringstad, L., and Slettemark, B., 1988. Paleoenvironmental changes in the Norwegian Sea and northeast Atlantic during the last $2.8 \mathrm{~m} . \mathrm{y}$.: Deep-Sea Drilling Project/Ocean Drilling Program Sites 610,642, 643, and 644. Paleoceanography, 3:563-581.

Johnson, D.A., and Knoll, A.H., 1974. Radiolaria as paleoclimatic indicators: Pleistocene climate fluctuations in the equatorial Pacific Ocean. Quat. Res. (N.Y.), 4:206-216.

Kutzbach, J.E., 1981. Monsoon climate of the early Holocene: climate experiment with the earth's orbital parameters for 9000 years ago. Science, 214:59-61.

Kutzbach, J.E., and Guetter, P.J., 1986. The influence of changing orbital parameters and surface boundary conditions on climate simulations for the past 18,000 years. J. Atmos. Sci., 43:1726-1759.

Kutzbach, J.E., and Otto-Bliesner, B.L., 1982. The sensitivity of the AfricanAsian monsoonal climate to orbital parameter changes for 9000 years B.P. in a low-resolution General Circulation Model. J. Atmos. Sci, 39:1177-1188.

Kutzbach, J.E., and Street-Perrott, F.A., 1985. Milankovitch forcing of fluctuations in the level of tropical lakes from 18 to zero kyrBP. Nature, 317:130-134.

Levitus, S., 1982. Climatological atlas of the world ocean. NOAA Prof. Pap., 13.

Lidz, B., Kehm, A., and Miller, H., 1968. Depth habitats of pelagic foraminifera during the Pleistocene. Nature, 217:245-247.

Lyle, M., 1988. Climatically forced organic carbon burial in equatorial atlantic and pacific oceans. Nature, 335:529-532.

Lyle, M., Prahl, F.G., and Sparrow, M.A., 1992. Upwelling and productivity changes inferred from a temperature record in the central equatorical Pacific. Nature, 355:812-815.

Lyle, M.W., Mix, A., and Pisias, N.G., 1991. Patterns of carbonate deposition in the eastern tropical Pacific Ocean for the last $150 \mathrm{Kyr}$ : evidence for a southeast Pacific depositional spike at 18 Ka. Eos, 72

Manabe, S., and Broccoli, A.J., 1983. Influence of the CLIMAP ice sheet on the climate of a general circulation model: implications for the Milankovitch theory. In Berger, A., et al. (Eds.), Milankovitch and Climate: Dordrecht (D. Reidel), 789-799.

Manabe, S., and Hahn, D.G., 1977. Simulation of the tropical climate of an ice age. J. Geophys. Res., 82:3889-3911.

Meyers, G., 1979. Annual variation in the slope of the $14^{\circ} \mathrm{C}$ isotherm along the equator in the Pacific Ocean. J. Phys. Oceanogr., 9:885-891.

Mix, A.C., Pisias, N.G., and Lyle, M.W., 1991. Spatial variability of circulation in the Eastern Tropical Pacific, 0-150,000 years: planktonic foraminifera, stable isotopes, and radiolaria. Eos, 72.

Moore, T.C., Burckle, L.H., Geitzenauer, K., Luz, B., Molina-Cruz, A., Robertson, J.H., Sachs, H., Sancetta, C., Thiede. J., Thompson, P., and Wenkam, C., 1980. The reconstruction of sea surface temperatures in the Pacific Ocean of 18,000 BP. Mar. Micropaleontol., 5:215-247.

Pedersen, T.F., 1983. Increased productivity in the eastern equatorial Pacific during the last glacial maximum (19.000 to $14,000 \mathrm{yr}$ B.P.). Geology, 11:16-19.

Philander, S.G.H., 1990. El Niño, La Niña and the Southern Oscillation: New York (Academic Press)
Philander, S.G.H., and Chao, Y., 1991. On the contrast between the seasonal cycles of the equatorial atlantic and pacific oceans. J. Phys. Oceanogr., 21:1399-1406.

Philander, S.G.H., and Pacanowski, R.C., 1980. The generation of equatorial currents. J. Geophys. Res., 85:1123-1136.

Pisias, N.G., Mix, A., and Lyle, M., 1991. Modes of sea surface temperature variability in the eastern equatorial Pacific during the last 150,000 years. Eos, 72.

Pisias, N.G., and Rea, D.K., 1988. Late Pleistocene paleoclimatology of the central equatorial Pacific: sea surface response to the southeast Trade Winds. Paleoceanography, 3:21-37.

Ravelo, A.C., 1991. Reconstructing the tropical Atlantic seasonal thermocline using planktonic foraminifera [Ph.D. thesis]. Columbia Univ., NY.

Ravelo, A.C., and Fairbanks, R.G., 1992. Oxygen isotopic composition of multiple species of planktonic foraminifera: recorders of the modern photic zone temperature gradient. Paleoceanography, 7:815-831.

Ravelo, A.C., Fairbanks, R.G., and Philander, G., 1990. Reconstructing tropical Atlantic hydrography using planktonic foraminifera and an ocean model. Paleoceanography, 5:409-431.

Raymo, M.E., Hodell, D., and Jansen, E., 1992. Response of deep ocean circulation to initiation of Northern Hemisphere glaciation (3-2 Ma). Paleoceanography, 7:645-672.

Raymo, M.E., Ruddiman, W.F., Shackleton, N.J., and Oppo, D.W., 1990. Evolution of global ice volume and Atlantic-Pacific $\delta^{13} \mathrm{C}$ gradients over the last 2.5 m.y. Earth Planet. Sci. Lett., 97:353-368.

Rind, D., 1987. Components of the Ice Age circulation. J. Geophys. Res., 92:4241-4281.

Ruddiman, W.F., and Raymo, M.E., 1988. Northern hemisphere climatic regimes during the past $3 \mathrm{Ma}$ : possible tectonic connections. Philos. Trans. R. Soc. London B, 318:411-430.

Sarnthein, M., Winn, K., Duplessy, J.-C., and Fontugne, M.R., 1988. Global variations of surface ocean productivity in low and mid latitudes: influence on $\mathrm{CO}_{2}$ reservoirs of the deep ocean and atmosphere during the last 21,000 years. Paleoceanography, 3:361-399.

Shackleton, N.J., 1968. Depth of pelagic foraminifera and isotopic changes in the pleistocene oceans. Nature, 218:79-80.

Shackleton, N.J., Berger, A., and Peltier, W.R., 1990. An alternative astronomical calibration of the lower Pleistocene timescale based on ODP Site 677. Trans. R. Soc. Edinburgh, Earth Sci., 81:251-261.

Shackleton, N.J., and Hall, M.A., 1984. Oxygen and carbon isotope stratigraphy of Deep Sea Drilling Project Hole 552A: Plio-Pleistocene glacial history. In Roberts, D.G., Schnitker, D., et al., Init. Repts. DSDP, 81: Washington (U.S. Govt. Printing Office), 599-609.

, 1989. Stable isotope history of the Pleistocene at ODP Site 677. In Becker, K., Sakai, H., et al., Proc. ODP, Sci. Results, 111: College Station, TX (Ocean Drilling Program), 295-316.

Shackleton, N.J., Imbrie, J., and Hall, M.A., 1983. Oxygen and carbon isotope record of East Pacific Core V19-30: implications for the formation of deep water in the late Pleistocene North Atlantic. Earth Planet. Sci. Lett., 65:233-244.

Shackleton, N.J., and Vincent, E., 1978. Oxygen and carbon isotope studies in recent foraminifera from the southwest Indian Ocean. Mar. Micropaleontol., $3: 1-13$.

Thunell, R.C., Curry, W.B., and Honjo, S., 1983. Seasonal variation in the flux of planktonic foraminifera: time series trap results from the Panama Basin. Earth Planet. Sci. Lett., 64:44-55.

Thunell, R.C., and Reynolds, L.A., 1984. Sedimentation of planktonic foraminifera: seasonal changes in species flux in the Panama Basin. Micropaleontology, 30:243-262.

Toggweiler, J.R., Dixon, K., and Broecker, W.S., 1991. The Peru upwelling and the ventilation of the south Pacific thermocline. J. Geophys. Res., 96:20467-20497.

Vincent, E., and Berger, W.H., 1981. Planktonic foraminifera and their use in paleoceanography. In Emiliani, C. (Ed.), The Sea (Vol. 7): The Oceanic Lithosphere: New York (Wiley Interscience), 1025-1119.

Williams, J., Barry, R.G., and Washington, W.M., 1974. Simulation of the atmospheric circulation using the NCAR global circulation model with ice age boundary conditions. J. Appl. Meteorol., 13:305-317.

Wyrtki, K., 1966. Oceanography of the eastern equatorial Pacific Ocean. Oceanogr. Mar. Biol. Ann. Rev., 4:33-68.

Date of initial receipt: 22 March 1993

Date of acceptance: 31 December 1993

Ms 138SR-126 